\title{
Language Experience Affects Comprehension of Spanish Passive Clauses: A Study of Heritage Speakers and Second Language Learners
}

\author{
Noelia Sánchez Walker * and Silvina Montrul * \\ Department of Spanish and Portuguese, University of Illinois at Urbana Champaign, Champaign, IL 61802, USA \\ * Correspondence: n.sanchez.walker@gmail.com (N.S.W.); montrul@illinois.edu (S.M.)
}

check for

updates

Citation: Sánchez Walker, Noelia; and Silvina Montrul. 2021. Language Experience Affects Comprehension of Spanish Passive Clauses: A Study of Heritage Speakers and Second Language Learners. Languages 6: 2. https://dx.doi.org/10.3390/ languages6010002

Received: 28 August 2020 Accepted: 15 December 2020 Published: 22 December 2020

Publisher's Note: MDPI stays neutral with regard to jurisdictional clai$\mathrm{ms}$ in published maps and institutional affiliations.

Copyright: $@ 2020$ by the authors. Licensee MDPI, Basel, Switzerland. This article is an open access article distributed under the terms and conditions of the Creative Commons Attribution (CC BY) license (https:// creativecommons.org/licenses/by/ $4.0 /)$.

\begin{abstract}
Heritage language (HL) learners of Spanish have shown better command with early acquired aspects of grammar than second language (L2) learners, mainly in oral tasks. This study investigates whether this advantage persists with passive clauses, structures acquired early but mastered during the school-age years, with literacy. We examined adjectival passives (La comida estaba servida, "Dinner was served") with the copula estar in the imperfect, which refer to a description of a state or a final result; and verbal passives with the copula ser in the imperfect (La comida era servida. "Dinner was being served"), which refer to an ongoing or habitual action in the past. A grammaticality judgment task (GJT) testing knowledge of the copulas in different simple sentences and a picture-matching task (PMT) testing the comprehension of the two passive clauses revealed that HL learners' knowledge of the copulas resembles that of literate monolingually raised native speakers more than that of L2 learners. HL learners are able to integrate their knowledge of the copulas to comprehend syntactically complex clauses, especially in the aural modality.
\end{abstract}

Keywords: passives; Spanish; bilingualism; heritage language acquisition; second language acquisition; later language development

\section{Introduction}

Early bilingual development in the United States is characterized by an uneven development of English and the minority language spoken at home (the heritage language). English becomes the dominant language of bilingual children as they assimilate to the mainstream culture through preschool, daycare or school, and typically, the minority language lags behind as exposure and opportunities to use it are considerably reduced. Studies of Spanish as a heritage language (HL) in the U.S. have found that adult early bilinguals' acquisition and development of English is successful, and that their knowledge of the minority language resembles that of monolingually raised native speakers (MRNS) of Spanish in several aspects, while also that of second language (L2) learners of Spanish in other aspects (Montrul 2016; Montrul et al. 2013, 2014; Montrul et al. 2008b; Foote 2011; Montrul 2005). However, most of these studies have focused on aspects of grammar acquired and mastered early, before age 5, when HL speakers are still at home surrounded by Spanish-speaking family. The present study shifts the focus from early acquired grammar to structures that emerge early but are mastered and fully developed later with literacy, during the school-age years. This is important in the context of the United States because academic instruction for most heritage speakers occurs in the majority language. English is overwhelmingly the primary, or only, language of instruction in elementary school. Our main goal is to find out how the linguistic experience of HL speakers affects knowledge of different types of passive clauses, which are more typical in written and academic language. We investigate whether HL speakers develop knowledge of passives like MRNS of Spanish, who experienced early Spanish input and literacy development in Spanish, or like 
instructed L2 learners, who acquired Spanish later in a formal environment primarily through written language.

\subsection{Linguistic Experience}

The age of meaningful exposure to a first and second language is assumed to be a robust predictor of successful L1 and L2 acquisition (Mayberry and Kluender 2018), but it is certainly not the only factor at play. As a result of the age and the context at which they were exposed, instructed Spanish L2 learners, HL speakers, and MRNS have different linguistic experiences, which impact their knowledge of the native, heritage, and second language.

A distinctive impact of the linguistic experience is the type of language knowledge that these groups develop: explicit or implicit knowledge. Explicit knowledge results from the conscious learning of grammar. It is also referred to as declarative knowledge of grammar because the learners are aware of what they are learning (R. Ellis 2008). Learners exposed to explicit knowledge can retrieve this knowledge on demand and perform well on tests that tap explicitly taught information (Loewen 2014; N.C. Ellis 2008). On the other hand, implicit knowledge of a language refers to having unconscious and automatic knowledge of the language (R. Ellis 2005, 2008, 2009; Rebuschat 2013; Loewen 2014), an example of which is situations when a speaker produces a sentence without consciously thinking about its grammatical correctness-that is, this language knowledge is automatized (DeKeyser 2017).

Broadly speaking, the linguistic experience of MRNS is characterized by monolanguage input from birth in a typically monolingual environment that includes becoming literate in the native language and experiencing the language in its various contexts, from mundane (paying bills, shopping, etc.) to formal (at school, work, church, community organizations). They have opportunities to engage in meaningful informal and formal conversations with different speakers in all these contexts. Exposure to spoken language during infancy fosters implicit knowledge of the language and the development of oral skills. In educated speakers, their linguistic experience involves exposure to written text and the formal standard register, as well as the development of writing skills. Since MRNS's literacy development occurs in Spanish, they can also develop metalinguistic knowledge of the language.

Bilingual native speakers' linguistic experience contrasts with that of MRNS because it is characterized by dual-language input, and language use is differentiated mainly by context. In the case of Spanish heritage speakers in the U.S., they are exposed from birth to their HL in a naturalistic environment with family and the community, and they are mostly engaged in oral interactions that foster their implicit knowledge of the language and their oral language skills. They typically have opportunities to engage in informal conversations with different types of speakers in the HL (e.g., grandparents, siblings, cousins, parents, community, etc.) but have limited or no opportunities to use the home language beyond the family, in formal settings or in writing. HL acquisition in an informal context does not involve the learning of grammar rules and developing metalinguistic knowledge in the HL. Since heritage speakers' linguistic experience is so varied, their ultimate attainment and proficiency in the HL ranges from fully fluent to minimal comprehension abilities (i.e., receptive bilinguals). Many heritage speakers are monolingual or dominant in the HL before age 5 because exposure to family input is quite consistent until that age, but language dominance shifts dramatically after that age, especially in the United States (Carreira and Kagan 2011), where the majority of the heritage speakers are schooled exclusively in English. Although their language interactions would typically be in both languages, after school entry, it would almost exclusively be in English in formal and academic contexts.

The earlier a child starts acquiring a majority language as a second language, the greater the impact on the heritage language (Montrul 2008b; Bylund 2009). The impact of learning two languages simultaneously at such an early age in a language minority situation and suboptimal levels of input in the L1 is reflected in weaker command of the 
heritage language, which often results in incomplete or partial acquisition (Montrul 2008b; Silva-Corvalán 2014; Domínguez et al. 2019a, 2019b; Montrul and Silva-Corvalán 2019; O'Grady et al. 2011)-a.k.a. "differential acquisition" (Kupisch and Rothman 2016; Bayram et al. 2019)—-language attrition or language loss (Montrul 2008b; Silva-Corvalán 1991; Montrul and Silva-Corvalán 2019), or both. Typically, incomplete or differential acquisition refers to a linguistic system that does not exhibit, or exhibits a variability of, grammatical properties that occur in the input and categorically in the linguistic system of MRNS. Thus, the grammar developed by heritage speakers diverges from that of MRNS. Language attrition refers to having acquired and later lost aspects of the grammar (changes in phonetics, phonology, morphology, syntax) due to long-term exposure to a majority language. Although language loss can have pathological causes, in typically developing bilingualism, language loss and incomplete or differential acquisition are related to the predominance of the majority language in the child's social context, qualitatively different input (Pires and Rothman 2009a, 2009b), and reduced opportunities to hear and actively use the HL (including lack of academic instruction in the HL) (Anderson 1999; Pires and Rothman 2009a, 2009b).

Instructed L2 learners' linguistic experience with Spanish in the U.S. differs from that of HL speakers in several ways. First, their meaningful exposure to the L2 is by choice. Second, exposure to Spanish typically starts in an instructed environment around middle school or high school and is mostly restricted to a few hours of class a week. Third, learning Spanish in this context exposes L2 learners to written texts and explicit explanations about grammar rules, and it gives them opportunities to develop reading and writing skills in the L2. However, it does not provide them with ample opportunities to use the L2 as a spoken language. Fourth, when L2 learners produce the language orally, it is generally limited to formal registers (oral presentation, oral exams, etc.) rather than to spontaneous situations in informal environments. Although some L2 learners can become highly fluent in the L2 (Montrul and Slabakova 2003; Jegerski 2012), their spoken language ability in the L2 varies greatly.

\subsection{Type of Knowledge and Task Effects}

HL and L2 speakers' linguistic experience influences their abilities with language tasks because each experience emphasizes different language skills. Having extensive practice with tasks that assess metalinguistic knowledge, instructed L2 learners tend to perform well in tasks that target metalinguistic knowledge (Montrul et al. 2008a; Bowles 2011a; Lichtman 2013). However, retrieving explicit knowledge of a language spontaneously, in real time, is cognitively costly and impairs communicative competence (Loewen 2014; Loewen and Sato 2017). When they rely on metalinguistic knowledge, fluent performance in real time, as in spoken language, is difficult for L2 learners (R. Ellis 2005).

In contrast, the language knowledge that HL speakers develop after exposure to their HL from birth is very much similar to that of MRNS; that is, implicit knowledge or procedural knowledge of the language (N.C. Ellis 2008). HL speakers are not conscious of this knowledge because they acquired it while using it. Similar to most native speakers who have not received (or never paid attention to) language instruction, HL speakers typically lack metalinguistic knowledge of their heritage language. When MRNS speak the language, they focus on the meaning they want to communicate rather than on the specific grammar they use. They typically base grammaticality judgments on whether constructions sound right or not (Loewen 2014; R. Ellis 2005; Rebuschat 2013). Similar to instructed L2 learners, HL speakers have reduced meaningful exposure to the language. Unlike L2 learners, HL speakers lack significant experience reading and writing the HL, and therefore, they have more implicit knowledge of the HL (Montrul 2008b, 2016). Implicit knowledge is accessed quickly without conscious awareness and thus allows for greater communicative competence (Loewen and Sato 2017). Since their experience with the language is mostly aural, HL speakers tend to show their language knowledge best in 
spoken and auditory tasks, which are better to tap into implicit knowledge (Bowles 2011a, 2011b; Montrul et al. 2008a).

Even though they have implicit knowledge of many aspects of the HL, young adult HL speakers do not command all areas of grammar of the HL to the same level. Hence, some of them enroll in Spanish courses to gain or regain knowledge of the HL and, at the same time, to gain confidence in their HL abilities. In the classroom, Spanish instruction presents metalinguistic information about the HL. Although research on HL instruction is still scarce, the few studies conducted to date show that formal instruction helps HL learners in their acquisition of specific grammatical constructions (Montrul and Bowles 2010; Bowles and Montrul 2008; Potowski et al. 2009; Bowles 2018). Thus, the amount of instruction in Spanish is yet another factor to consider when studying HL learners' linguistic experience.

Research has shown that language experience in the classroom affects the linguistic performance of HL speakers and L2 learners in different tasks, which is important to fully characterize their grammatical knowledge. For instance, Bowles (2011a) studied spoken classroom interactions between HL and L2 learners to see how the two types of learners negotiate linguistic gaps during interaction. She found that the HL learners relied on their linguistic intuition to provide vocabulary and grammar information requested from the L2 learners, while the L2 learners relied on their metalinguistic knowledge of orthography when aiding HL learners. Torres (2018) manipulated task complexity to study how different types of instruction affected the development of the Spanish subjunctive and found that L2 and HL learners' performance reflected their HL/L2 language experience. While both groups retained knowledge of the subjunctive in the oral production tasks used, the L2 learners showed more gains in the written production task. Torres's findings also revealed that the two groups approached these tasks differently: while HL learners focused on meaning rather than form, the L2 learners focused more on form and tried to form rules (see also Potowski et al. 2009). Several studies have shown a relationship between mode of acquisition and task modality in HL speakers and L2 speakers (Montrul et al. 2008a; Montrul 2010, 2011; Montrul et al. 2014), which underscore the effect of experience with the language (Montrul et al. 2014).

Thus, despite age being a robust predictor for L2 acquisition, linguistic experience affects the assessment of these speakers' knowledge of the language depending on the modality of the instrument. Moreover, Spanish instruction also affects speakers' knowledge of the language. These facts are important in measuring and understanding L2 and HL acquisition as researchers identify vulnerable areas in different linguistic domains of the L2/HL.

The present study contributes to the growing body of research on the characterization of the grammatical knowledge that HL speakers acquire and develop by investigating the written and auditory comprehension of adjectival and verbal passives in populations with different linguistic experience. Although both passives are acquired early in childhood, only verbal passives are structures of later language development. By comparing how HL learners' grammar differs from that of MRNS and L2 learners, we will gain a deeper understanding of how language experience, including varying degrees of academic instruction in Spanish, affects later language development. With this information, we will be in a better position to inform current pedagogical decisions regarding which aspects of grammar need to be the focus of HL and L2 instruction and on the types of language tasks that are most beneficial for HL and L2 learners.

The next section describes the language structures investigated in this study.

\subsection{Passive Clauses}

Passive clauses are structurally more complex than their active forms, although they convey the same meaning. The agent subject and the theme direct object from an active sentence, as in (1), undergo a movement transformation by which the theme becomes the 
syntactic subject, while the agent is demoted to an oblique prepositional phrase in a passive sentence, as in (2).

1. Active Sentence

\begin{tabular}{|c|c|c|}
\hline $\begin{array}{l}\text { El papá } \\
\text { the father-M.SG } \\
\text { subject/agent }\end{array}$ & $\begin{array}{l}\text { sirvi-ó } \\
\text { serve-PRET.SG }\end{array}$ & $\begin{array}{l}\text { la cena. } \\
\text { the dinner-F.SG } \\
\text { direct object/theme }\end{array}$ \\
\hline
\end{tabular}

"The father served dinner."

2. Passive Sentence

$\begin{array}{llll}\begin{array}{l}\text { La cena } \\ \text { the dinner-F.SG } \\ \text { subject/theme }\end{array} & \begin{array}{l}\text { fue } \\ \text { be-ser-PRET.SG }\end{array} & \begin{array}{l}\text { serv-ida } \\ \text { serve-PTCP.F.SG }\end{array} & \begin{array}{l}\text { por el papá. } \\ \text { by the father-M.SG } \\ \text { oblique prepositional phrase/agent }\end{array}\end{array}$

"Dinner was served by the father."

In addition to the reorganization of the elements of the sentence, a complication is that a passive sentence can be either adjectival or verbal (O'Grady 1997). Verbal passives denote an event and are also known as eventive passives. Example (2) is a verbal passive, which involves a syntactic movement (Borer and Wexler 1987; Pierce 1992; Grodzinsky 2000; Ud Deen 2011). The syntactic movement of the subject and object noun phrases in verbal passives is what re-orders the typical Subject-Verb-Object word order in many languages (Grodzinsky 2000; Ud Deen 2011). This syntactic movement requires interlocutors to reassign semantic roles that were initially based on sentence position and properties of the noun (e.g., sentence initial, animate noun phrases tend to be agents) (Huang et al. 2013). The object (theme) gets its thematic role from the verb and then becomes the subject because it moves to the specifier position of the tense phrase (TP) to check the nominative case, leaving a trace. This is also known as A-movement. Since the participial form absorbs the agent role, the agent becomes optional, and if expressed overtly, it is projected in an adjunct prepositional phrase.

Adjectival passives, as in (3), are structurally less complex because they do not involve A-movement: the theme is base generated in subject position, and the participle is the attribute as in a typical adjectival construction (Borer and Wexler 1987; Grimshaw 1990). Since adjectival passives denote a state, they are also known as stative passives.
3. (Ella)
Esta-ba be-estar-IMPERFECT.SG
impresión-ada.
'She)
impress-PTCP.F.SG

In Spanish, the verbal passive is also known as a periphrastic passive and is considerably less frequent than the morphological passive or se-passive (e.g., El libro se escribió en México. "The book was written in Mexico."), which is the preferred option for downgrading agency in Spanish. Unlike verbal passives in English, verbal passives in Spanish are quite infrequent in the input (Green 1975; Quesada 1997; Takagaki 2005) and are typically used in writing (i.e., newspapers, literature, etc.) (Pierce 1992). Their use becomes productive in spoken language after exposure to written language (Jisa et al. 2002; Tolchinsky and Rosado 2005).

Although verbal and adjectival passives are structurally different, in English, they look alike on the surface. Participles in English help differentiate between verbal and adjectival passives. Adjectivized participles, but not verbal passives, can be expressed with the negative prefix 'un-', or with degree words (i.e., very) (O'Grady 1997; Wasow 1977), see (4) and (5) taken from (O'Grady 1997, p. 192).
4.
(a)
Verbal Passives
(b)
The book was put on the shelf.
Harry was hit by the ball.
*The book was unput on the shelf.
*Harry was very hit by the ball.
5. Adjectival Passives
(a) The island is inhabited. The island is uninhabited.
(b) The teacher was annoyed. The teacher was very annoyed.

In Spanish, verbal and adjectival passives are expressed with a different copula. Each copula brings its own temporal interpretation of the clause. Verbal passives, as shown 
in (6), are expressed with ser. They present an event that occurs during the specific time indicated by the tense and aspect of the copula ser.

6. Verbal/Eventive Passive

$\begin{array}{llll}\text { La casa } & \text { er-a } & \text { edific-ada } & \text { (por la compañía). } \\ \text { the house-F.SG } & \text { be-ser- } & \text { build-PTCP.F.SG } & \text { (by the company) } \\ \text { "The house was being built (by the company)." } & \end{array}$

Adjectival passives, shown in (7), are expressed with estar. As in English, the past participle in the adjectival passives describes a state, a result, a finished action.

7. Adjectival/Stative Passive

$\begin{array}{lll}\text { La casa } & \text { esta-ba } & \text { edific-ada. } \\ \text { the house-F.SG } & \text { be-estar-IMPERFECT.SG } & \text { build-PTCP.F.SG } \\ \text { "The house was built." } & \end{array}$

It has often been assumed that adjectival passives do not allow an adjunct agent, do not carry an implicit agent, and are ungrammatical with a displaced agent, as in (8). However, new research has uncovered that the grammaticality of adjectival passives with agent por-phrases depends on many factors that are beyond the scope of this paper, including the (in)definiteness of the noun phrase in the por-phrase (Varela 1992; Gehrke and Marco 2014). In this study, we did not use indefinite agents.

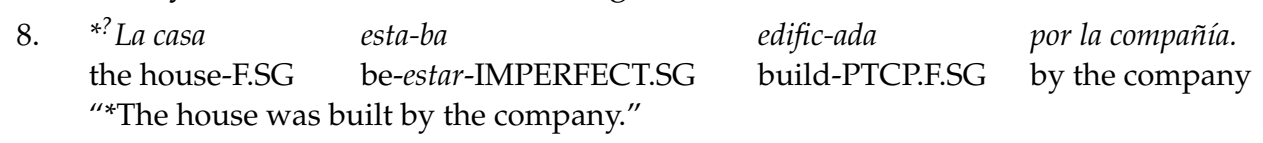

Notice that unlike the past participle of an adjectival or verbal passive in English, the Spanish past participle has to agree in number and gender with the subject. Subject and participle agreement adds to the structural complexity of passives, especially if the theme and agent are animate, as in (9) and (10).

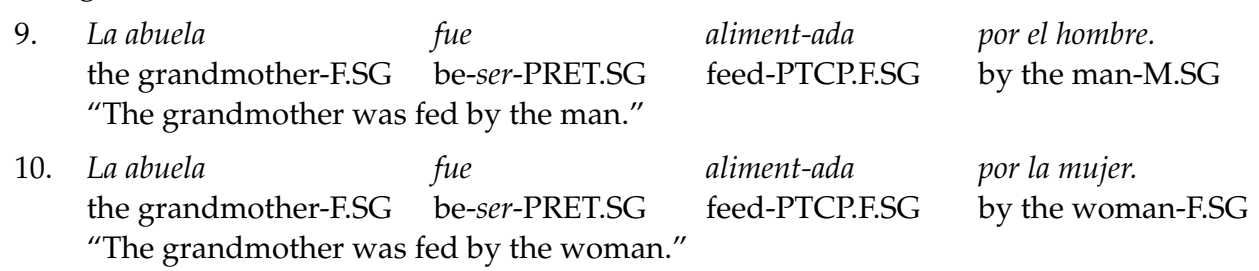

Furthermore, Spanish is a null subject language and can have VS order or appear with no subject, as in (11) and (12).
11. Fue
be-ser-PRET.SG feed-PTCP.F.SG
"The grandmother was fed by the man."
12. Fue
be-ser-PRET.SG feed-PTCP.F.SG
"A female/She was fed by the man."
$\begin{array}{ll}\text { la abuela } & \text { por el hombre. } \\ \text { the grandmother-F.SG } & \text { by the man-M.SG }\end{array}$
por el hombre.
by the man-M.SG

Passives have been the focus of many language acquisition studies (Armon-Lotem et al. 2016; Crawford 2012; Ud Deen 2011; Crain et al. 2009; O'Grady 1997; Fox and Grodzinsky 1998; Pinker et al. 1987). Adjectival passives in Spanish (Él está colgado de la cabra. "He is hung from the goat.") are acquired by 4 years of age (Berman and Slobin 1994); irreversible verbal full passives in Spanish (e.g., Maria fue lavada por Juan. "Maria[FEM SING]

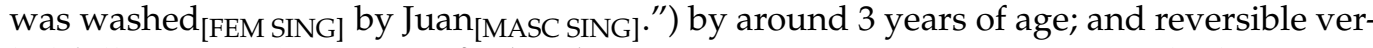
bal full passives (e.g., Maria fue lavada por Laura. "Maria [FEM SING] was washed ${ }_{\text {[FEM SING] }}$ by Laura[FEM SING].") by 5 or 6 years of age (Pierce 1992). Although acquired relatively early, full command and use of verbal passives are achieved during the school-age years (Pierce 1992; Jisa et al. 2002; Tolchinsky and Rosado 2005). Factors that contribute to the difficulty of the verbal passive include their low frequency in the input, syntactic move- 
ment, and the optionality of the by-phrase. Borer and Wexler $(1987,1992)$ attribute the difficulty to the biological maturation of A-chains, and Fox and Grodzinsky (1998) attribute the difficulty to children's inability to extend non-actional verb theta-role assignment to the $b y$-phrase.

A factor to consider in the acquisition of ser and estar is aspect. English and Spanish map meaning to form differently, and this is problematic for the acquisition of the aspectual distinction of the copulas in Spanish (Montrul 2008b). ${ }^{1}$ The copula be in English does not instantiate aspectual distinctions through morphology, but it does it by means of other elements in the sentence. Spanish estar is marked as perfective (Bruhn de Garavito and Valenzuela 2008), and it is considered an aspectual auxiliary (Lema 1992). The attribute introduced by estar is a result, an action completed, or a quality of the subject. On the other hand, the participles appearing with ser can be perfective or imperfective (Bruhn de Garavito and Valenzuela 2008). Used as verbal auxiliary in the passive, ser emphasizes the action that is occurring without reference to beginning or endpoint. The point in time when this ongoing action or event is taking place is determined by the tense: if the passive is constructed with the preterite past tense fue, the action has already occurred, but if the imperfect tense era is used instead, the action is interpreted as occurring in the past. The mapping problem for L2 learners of Spanish is that English encodes in the form "to be" what Spanish encodes in ser and estar. So, one meaning with one form needs to be expressed by two meanings with two forms. Since the two passives depend on the copula form in Spanish, L2 learners must acquire two new irregular morphological forms of the copula, their syntactic complementary distribution (Camacho 2012), and their semantic and pragmatic contrast while mapping meanings onto forms (Geeslin 2003, 2013; Bruhn de Garavito and Valenzuela 2006; Briscoe 1995). These tasks involve "the coordination of grammatical knowledge at the interface between morphology, semantics and syntax, and it causes obvious delays in acquisition" (Montrul 2008a, p. 338).

Bruhn de Garavito and Valenzuela (2008) investigated the acceptability of verbal and adjectival passives with an acceptability judgment task. Native speakers (NS) and advanced L2 learners evaluated the acceptability of grammatical and ungrammatical sentences on a scale from 1 (totally unacceptable) to 5 (totally acceptable). L2 learners, but not the NS, had difficulty accepting adjectival passives with estar in the imperfect tense, as in (13). Both groups accepted adjectival passives with estar in the present tense (e.g., La cena ya está preparada para la fiesta. "The dinner is already prepared for the party.").

\begin{tabular}{|c|c|c|c|c|}
\hline $\begin{array}{l}\text { Ayer } \\
\text { yesterday }\end{array}$ & $\begin{array}{l}\text { la comida } \\
\text { the dinner-F.SG }\end{array}$ & $\begin{array}{l}\text { esta-ba } \\
\text { be-estar-IMPERFECT.SG }\end{array}$ & $\begin{array}{l}\text { serv-ida } \\
\text { serve-PTCP.F.SG }\end{array}$ & $\begin{array}{l}\text { en la mesa. } \\
\text { on the table }\end{array}$ \\
\hline
\end{tabular}

Both groups gave verbal passives with the copula in the imperfect tense, (14), lower acceptability ratings.

$\begin{array}{llll}\text { 14. El libro } & \text { er-a } & \text { escr-ito } & \text { en inglés. } \\ \text { the book-M.SG be-ser-IMPERFECT.SG } & \text { write-PTCP.M.SG } & \text { in English } \\ & \text { "The book was being written in English." }\end{array}$

And both groups evaluated verbal passives with canonical past tense fue, as in (15), as acceptable.
15. El
libro
fue
be-ser-PRETERITE.SG
escr-ito
write-PTCP.M.SG
en Inglaterra.
the book-M.SG be-ser-PR

Native speakers, but not L2 learners, accepted verbal passives in the present tense (e.g., En el consulado los documentos son entregados durante las horas de oficina. "In the consulate, documents are handed in during office hours.").

1 See Archer et al. (2019) for more on complexity of copulas. 
Results in Bruhn and Valenzuela's study confirm the frequency of verbal passives in general and particularly the infrequency of verbal passives with the copula in the imperfect tense: although categorically permitted, and used in formal contexts, they are not preferred by native speakers, even if they understand them (Green 1975; Diego Quesada 1997; Takagaki 2005). ${ }^{2}$ Many explanations have been put forth to explain these preferences, among them the complexity of verbal passives. We refer the reader to the cited work for more details. Of concern to us is that although native speakers of Spanish give low acceptability ratings to verbal passives with era (at least when presented out of context), they still comprehend them. L2 learners give low acceptability ratings to these passives, but it is unclear whether they understand them or not.

Regarding heritage speakers, Silva-Corvalán and Montanari (2008) found that a Spanish-English bilingual child between the ages 1;6 and 2;11 produced passives in Spanish without the copula ser at age 2;1, and Vasilyeva et al. (2010) found that by ages 5;2-6;5 Spanish-English bilingual children have the representation of full passives in Spanish. However, the approximate length of time it takes for bilingual children to acquire the semantics of ser and estar remains inconclusive. Monolingual children acquire the semantic differences of the two copulas by age 4 (Schmitt and Miller 2007). A case study of an English-Spanish bilingual child growing up in a Spanish-speaking country (Krasinski 2005) found that it took the child longer to acquire the difference between ser and estar than monolingual children by age 4;2. Meanwhile, the Spanish-English bilingual child that Silva-Corvalán and Montanari (2008) studied produced adjectival participles (e.g., mojado "wet", tapada "covered", ending in -ado/-ido) with the verb estar exclusively, he also showed delayed acquisition of estar. These data suggest that even if bilinguals have the representation of the canonical passive (e.g., La casa fue edificada por la compañia, "The house was built by the company"), they might struggle with the distinction between ser and estar, which is essential for understanding verbal and adjectival passives.

Studies on adult early bilinguals show that this is the case. Valenzuela et al. (2015) replicated Bruhn de Garavito and Valenzuela (2008) and administered the acceptability judgment task to twenty-two heritage speakers of Spanish described as having "near-native proficiency". Similar to L2 learners, heritage speakers judged verbal passives with fue as acceptable. They also rated adjectival passives with estar in the imperfect tense, and adjectival and verbal passives with the copulas in the present tense more acceptable than verbal passives with ser in the imperfect tense, the latter receiving the lowest acceptability rating. However, as with L2 learners, we have yet to find out whether HL learners understand the meaning of this structure.

\subsection{Passives with Copulas in the Imperfect Tense}

The imperfect tense poses difficulty to L2 learners (Montrul and Slabakova 2003; Montrul and Perpiñán 2011; Comajoan Colomé 2014), and to heritage speakers of Spanish (Montrul and Perpiñán 2011; Merino 1983; Silva-Corvalán 1994, 2003). Montrul and Slabakova (2003) and Montrul and Perpiñán (2011) specifically tested acquisition of preterite and imperfect morphology and their semantic implications by L2 learners and heritage speakers. L2 learners of Spanish with near native proficiency were indistinguishable from the native speakers, and while L2 learners of lower proficiency recognized the imperfect morphology better than the heritage learners, heritage speakers of low and intermediate proficiency showed better understanding of the preterite/imperfect contrast. These studies show that, although difficult, the semantic implications of the imperfect tense can be acquired by L2 and heritage learners of Spanish. However, L2 learners struggle to learn and understand all the intricacies of the copulas' grammar and use, and L2 instructors struggle to teach them (Montrul 2008a). This means that instructed L2 learners and HL

2 Before conducting the present study, a pilot study was conducted by one of the authors to test native speakers' comprehension of verbal passives. The study confirmed that they understood this structure. 
learners are not usually taught in detail the syntactic complementary distribution of the copulas in grammar constructions.

Monolingually raised native speakers (MRNS) know the meaning of the two passive forms. If the learners show knowledge of ser and estar in different simple sentences but difficulties in comprehending verbal and adjectival passives, the difficulties may likely be due to their unfamiliarity with how the aspectual properties of the copulas relate to the semantics of verbal and adjectival passives.

To summarize, verbal passives are syntactically more complex than adjectival passives. The semantics and aspectual form of the copulas add additional challenges for HL and L2 learners, especially when the aspectual form of the verb (present, preterite or imperfect) clashes with the meaning of the passive (verbal passives with ser are eventive, adjectival passives with estar are stative). HL and L2 learners accept verbal passives with the copula in the preterite fue, but not when the copula is in the past imperfect era. The HL learners are more accepting than the L2 learners of adjectival passives with estar in the imperfect. Therefore, we investigate whether HL learners have less difficulty than L2 learners with the comprehension of the estar/ser contrast in the past imperfect in adjectival and verbal passives.

Furthermore, based on their linguistic experience MRNS, L2 and HL learners develop different strengths. L2 learners with classroom experience that prioritizes written language and grammar rules tend to show better linguistic knowledge in tasks that tap metalinguistic knowledge. By contrast, HL learners, who bring informal and home experience with the language, tend to perform better in tasks that tap implicit knowledge. We ask whether this tendency also exists in the acquisition of structures of later language development. Literate MRNS tend to perform well in both types of tasks.

Finally, since verbal passives are more common in written language, exposure to written language through language instruction becomes relevant. Both groups of learners differ in type and amount of Spanish instruction received. Thus, we also ask whether amount of previous Spanish instruction affects comprehension of passives.

Summing up, the following research questions guide our study:

1. Are HL learners and L2 learners more accurate in the comprehension of adjectival passives than in the comprehension of verbal passives?

2. Even though passives are acquired later in childhood, does early exposure to Spanish give HL learners an advantage (i.e., more MRNS-like knowledge) over L2 learners in the comprehension of passives?

3. Does task modality affect the comprehension of passive clauses for these two groups?

4. Does the amount of instruction affect the comprehension of passive clauses for these two groups?

\subsection{Hypotheses}

We expect all learners to be more accurate in the comprehension of adjectival passives because they are a syntactically simpler and more frequent than verbal passives.

As a result of their early language experience, we expect HL learners to be more accurate than L2 learners in the comprehension of adjectival passives. Aspectual distinctions of the copula in Spanish are hard to acquire for L2 and HL learners. Even if they have the representation of the canonical full passive, HL and L2 learners experience a delay in acquiring the semantics of ser and estar. Thus, HL learners are not expected to be more accurate than L2 learners in the comprehension of verbal passives with the copula in the imperfect tense because these clauses are not very frequent in the input, and the use of passives increases as literacy develops and learners develop knowledge of formal registers.

HL learners' linguistic experience helps them perform better in tasks that tap implicit knowledge, and L2 learners' experience helps them with tasks that tap explicit knowledge. Therefore, HL learners are expected to perform better in the aural modality because this modality taps implicit knowledge and L2 learners are expected to perform better in the written modality because this modality taps their explicit knowledge. 
The last question addresses Spanish instruction. Instruction exposes students to written language and formal texts. Therefore, learners who have completed more Spanish courses and have a higher level of proficiency are expected to show better comprehension of passives than learners who took fewer courses and have lower proficiency, because the probability of having acquired the copula distinction is higher with advanced proficiency in Spanish.

\section{Materials and Methods}

\subsection{Participants}

Monolingually raised native speakers (MRNS), HL learners, and L2 learners were recruited through email announcement and flyers at the participating institutions in the United States. All participants were tested individually and remunerated ten dollars per hour. Completion of all tasks and questionnaires took approximately one and a half hours to two hours.

A background questionnaire with questions about demographic information, language experience, family language background, and Spanish instruction was administered to all participants. See the questionnaire in Appendix E.

The MR native speakers' mean age was 29.93 (SD =6.28). Their mean length of residence in the U.S. was 56.13 months $(\mathrm{SD}=48.98)$ and ranged from half a month to sixteen years (192 months); see Table 1. Only two native speakers arrived in the US before age eighteen. One arrived at age fifteen, and was nineteen at the time of testing; the other one arrived at age twelve and was twenty-eight at the time of testing. A native speaker from Spain was excluded because she was a heritage speaker of Romanian.

Table 1. Participants' profile.

\begin{tabular}{|c|c|c|c|}
\hline & MRNS & HL Learners & L2 Learners \\
\hline & $\mathrm{n}=\mathbf{3 0}$ & $\mathbf{n}=33$ & $\mathrm{n}=\mathbf{3 1}$ \\
\hline Mean age (SD) & $29.93(6.28)$ & $22.64(6.02)$ & $23.29(5.42)$ \\
\hline range & $19-47$ & $18-43$ & $18-39$ \\
\hline Country $^{1}$ & $\begin{array}{l}\text { Chile, Colombia, Cuba, } \\
\text { Dominican Republic, } \\
\text { Ecuador, Mexico, Peru, } \\
\text { Puerto Rico, Spain }\end{array}$ & $\begin{array}{c}\text { Argentina, Colombia, } \\
\text { Dominican Republic, } \\
\text { Ecuador, Guatemala, Mexico, Peru, } \\
\text { Puerto Rico, Spain }\end{array}$ & \\
\hline $\begin{array}{l}\text { First meaningful exposure } \\
\text { to Spanish }\end{array}$ & birth & birth & Middle school \\
\hline $\begin{array}{l}\text { Length of meaningful exposure } \\
\text { to English }\end{array}$ & 2 weeks-16 years & Age 5 mostly (for some since daycare) & birth \\
\hline \multicolumn{4}{|l|}{ Written Proficiency (DELE) } \\
\hline Mean Score (SD) & 47.63 (1.99) & $38.58(6.82)$ & $35.03(8.20)$ \\
\hline DELE range & $42-50$ & $15-50$ & $25-47$ \\
\hline \multicolumn{4}{|l|}{ Oral Proficiency Mean Scores (SD) } \\
\hline MATTR & $0.56(0.05)$ & $0.52(0.04)$ & $0.50(0.05)$ \\
\hline MATTR range & $0.46-0.66$ & $0.44-0.59$ & $0.39-0.59$ \\
\hline MLU & $10.43(2.83)$ & $9.16(1.80)$ & $9.95(1.68)$ \\
\hline MLU range & $6.00-16.55$ & $5.93-13.09$ & $7.16-14.25$ \\
\hline Fluency (words/minute) & $108.57(23.42)$ & $88.40(23.84)$ & $72.571(21.88)$ \\
\hline Fluency range & $41.2-149.49$ & $49.15-134.27$ & $47.76-128.28$ \\
\hline Spanish courses (SD) & - & 8.2 courses $(8.0)$ & 14.1 courses $(9.4)$ \\
\hline Courses range & & 1-35 courses & 3-38.5 courses \\
\hline
\end{tabular}

${ }^{1}$ For MRNS, "country" refers to the country where they grew up (2 Mexico, 4 Chile, 3 Colombia, 1 Dom Rep, 4 Ecuador, 6 Perú, 4 Puerto Rico, 1 Cuba, 6 Spain). For HL learners, it refers to the country where their parents came from (18 Mexico, 2 Argentina, 4 Dominican Republic, 1 Ecuador, 2 Guatemala, 3 Puerto Rico, 1 Spain, 1 Colombia-Puerto Rico, 1 Venezuela-Spain). 
The HL speakers' mean age was $22.64(\mathrm{SD}=6.02)$; see Table 1. All HL speakers were born in the U.S., except for four. Two were born outside the U.S. and came to the U.S. at the age of one and at the age of six months. The other two were born outside the U.S., but one came to the U.S. after age four. They were removed from data analysis because only participants who arrived in the U.S. before age three were included. All heritage speakers started Kindergarten in the U.S., and four attended elementary schools with dual language programs (Spanish-English).

L2 speakers' mean age was 23.29 (SD = 5.42). They acquired English from birth, and most of them started learning Spanish in middle school or high school, at the age of eleven or later (range 11-17). However, for eleven participants, first exposure to Spanish as a foreign language was in elementary school starting as early as Kindergarten.

Since this study assessed comprehension in written and aural modality, proficiency in Spanish was determined with a written proficiency test and an oral picture-based narrative task. The written test was adapted from the Diploma de Español como Lengua Extranjera (DELE) and consisted of thirty multiple-choice vocabulary questions and a twenty-gap cloze test. This test has been used to test the proficiency of Spanish as a heritage language in numerous studies (Montrul 2016). Oral proficiency was determined using an oral picturebased narrative. Participants watched a Power Point picture presentation of the story of Little Red Riding Hood and were asked to describe and narrate fourteen pictures. Instructions were in Spanish. Audio files were transcribed and analyzed using the Systematic Analysis of Language Transcripts (SALT) software student version 16-7 (Miller and Iglesias 2016). From the measures reported by SALT, we used moving average type/token ratio (MATTR) for lexical diversity, mean length of utterance (MLU) in words, and lexical fluency (words per minute) to indicate oral proficiency.

L2 learners who scored below twenty-five (out of fifty maximum) in the written proficiency test were excluded $(n=18)$. Exclusion of these L2 learners was necessary for comparison purposes because thirty-two of the thirty-three HL speakers fell within the 26-50 proficiency range, and more importantly, because we reasoned that beginner learners of Spanish would not be able to understand complex sentences. The only HL speaker who scored below twenty-six in the written proficiency test was not excluded because he was more fluent than fifteen of the L2 learners included in the study, as measured by the lexical fluency analysis.

A total of ninety-four participants were kept for data analysis: thirty native speakers, thirty-one L2 learners, and thirty-three heritage speakers. Participants' profiles and proficiency scores appear in Table 1.

Spanish instruction in the U.S. was operationalized as number of courses completed in school and college. Note that Spanish courses at school are typically a full academic year, whereas college courses are one semester. Thus, one year of Spanish at school counted as two courses. Native speakers' attended school and college in their countries. Four heritage speakers and one L2 learner attended bilingual or two-way immersion elementary schools, but the number of years in these programs varied. Some L2 learners had completed graduate courses in Spanish. Some HL and L2 learners had participated in study abroad programs of different lengths of time, ranging from two weeks to almost two years. Given the wide variability of study abroad experiences, only Spanish courses completed in the U.S. were considered for data analysis.

A one-way ANOVA was conducted in StatPlus:mac Pro Version v7 (AnalystSoft Inc. 2019) on each proficiency measure to verify if groups differ significantly.

Analysis of the written proficiency measure (DELE) showed a main effect of group $(F(2,91)=33.98, p<0.001)$. Bonferroni-corrected post-hoc comparisons indicated that DELE scores of native speakers were significantly different from the scores of the HL learners and of the L2 learners $(p<0.001)$. The difference between HL and L2 learners scores was not significant $(p=0.08)$.

Moving average type/token ratio (MATTR) scores analysis of the oral narrative showed a main effect of group $(F(2,91)=13.84, p<0.001)$. Bonferroni-corrected post-hoc 
comparisons indicated that native speakers' MATTR scores were significantly different from that of the HL $(p<0.001)$ and the L2 learners' $(p=0.006)$. The HL and L2 learners did not differ significantly from each other $(p=0.10)$.

There was a main effect of group in the analysis of MLU scores $(F(2,91)=3.62, p=0.03)$. Bonferroni-corrected post-hoc comparisons indicated that the difference between native speakers and L2 learners scores was not significant $(p=0.98)$, and neither was the difference between HL and L2 learners' scores $(p=0.30)$. HL learners MLU score was significantly lower than the native speakers' MLU score $(p=0.03)$.

Analysis on fluency (words/minute) scores also showed a main effect of group $(F(2,91)$ $=18.62, p<0.001)$. Post-hoc comparisons indicated that fluency scores for all three groups differed significantly from each other: native speakers from L2 learners $(p<0.001)$, and native speakers from HL learners $(p=0.002)$, with native speakers being the most fluent and L2 learners the least fluent.

The mean Spanish instruction for L2 learners was 14.1 courses $(\mathrm{SD}=9.4)$, and the mean Spanish instruction for HL learners was 8.2 courses $(\mathrm{SD}=8.0)$.

\subsection{Tasks}

To test accuracy in the comprehension of adjectival passives and verbal passives, a picture-matching task (PMT) in aural and written modalities was designed. However, because the PMT tested comprehension of passives with copulas in the imperfect, a grammaticality judgment task (GJT) was also designed to ensure that inaccuracy in the comprehension of passives was not due to the low acceptability of the copulas in the imperfect. We reasoned that if the GJT shows high acceptance of copulas in the imperfect, and the PMT shows low accuracy in the comprehension of passives, that would mean that participants had difficulty with the passives, not with the imperfect.

Participants completed the aural PMT first, the written PMT second, the aural GJT third, and the written GJT fourth. Once they were done with the PMT and the GJT, they completed the written proficiency test, the bilingual language questionnaire, and the oral narrative in no specific order, depending on the availability of computers. A Mexican speaker recorded most of the PMT and GJT sentences. A Puerto Rican speaker recorded some of the PMT sentences and some of the GJT grammatical and ungrammatical sentences. No pattern in terms of one speaker being favored over another was found.

\subsubsection{Picture-Matching Task (PMT)}

The picture-matching task (PMT) was designed in the psycholinguistics software E-Prime 2.0 to test the comprehension of passive clauses. Participants listened to or read a sentence and then selected the picture depicting what they had just heard or read.

\section{Norming}

The two main components of the PMT were the drawings and the sentences. Before creating the PMT, all drawings and sentences were normed.

Each sentence and drawing was based on a context. For instance, to depict "The car was vandalized" and "The car was being vandalized", two drawings were needed: one for each action. There were twenty-four contexts for the passives. Hand-drawn pictures for all contexts were judged by three undergraduate students for clarity. The students were asked to explain the drawings and to mark the drawings that they could not explain. Drawings were modified for clarity based on the feedback received.

Plausibility of the context affects the comprehension of passives; therefore, all passive sentences were normed with native speakers to make sure that plausibility of the context did not affect selection of the drawings. Norming of the sentences was conducted through Surveygizmo. Twenty-five passives were judged by eighteen Spanish native speakers from Puerto Rico ( $n=15)$, Mexico $(n=2)$, Perú $(n=1)$, and by one near-native Spanish L2 learner from Brazil. Seven of these participants lived in the U.S. at the time of testing. These 
nineteen participants completed the Surveygizmo task only; they did not complete any other tasks.

The norming study elicited "plausibility ratings" of verbal passives with displaced agents (e.g., El paciente era medicado por los médicos. "The patient was being medicated by the doctor."), and of other basic declarative sentences. The norming study was entirely in Spanish. No translation was provided. After norming was completed, the contexts from the passives considered least plausible were excluded. Twenty-four contexts for verbal passives were included in the PMT.

Twenty-four verbal passive contexts were created as minimal pairs with twenty-four adjectival passives so that the only difference between them was the copula, as in (16). All experimental sentences and drawings appear in Appendix G. By showing participants a picture depicting an ongoing action and the other depicting a finished action using the same past participle, and by limiting the amount of time participants had to comprehend the sentences, this task minimized learners' access to metalinguistic knowledge and forced them to focus on the meaning of the sentence in each modality. In this way, this study taps modality effects in the comprehension of these sentences.
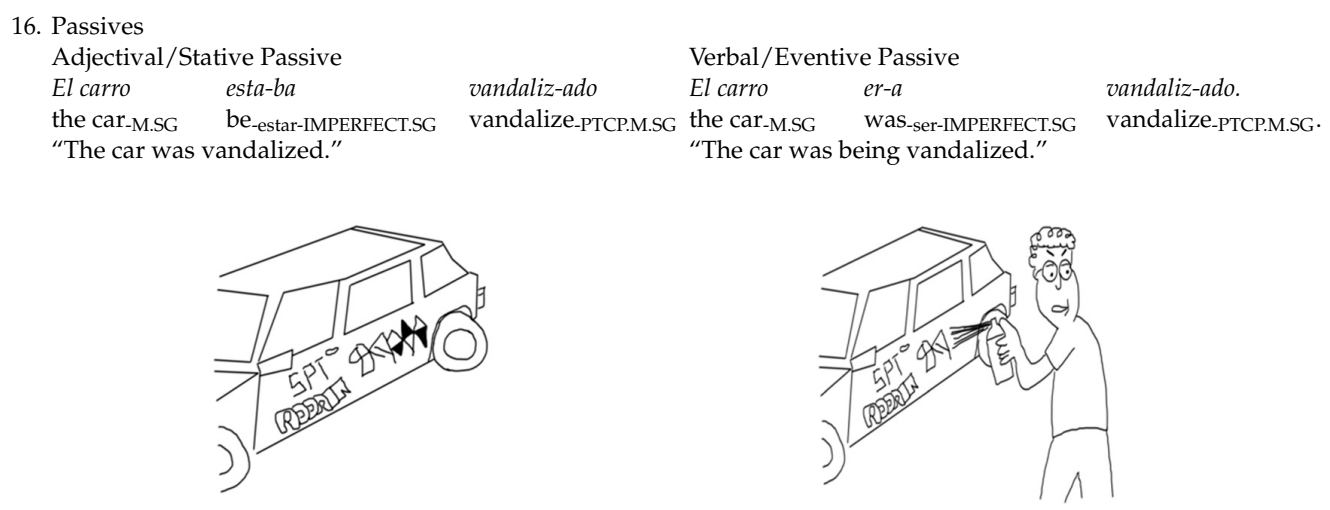

Since one of the goals of the present study was to investigate knowledge of the semantics of ser and estar in a passive, only truncated passives were used in the experimental clauses. Omitting the agent avoided leading the participants to a particular interpretation. To avoid other confounds, only actional verbs were used, because these are the verbs that are first understood in L1 acquisition and the development of passive clauses (Sudhalter and Braine 1985). Actional verbs change the subject or affect the subject (e.g., "to vandalize") as opposed to experiential verbs that do not change the subject (e.g., "to see"). The irreversibility of verbal passive clauses (whether the agent or the theme could perform the action expressed by the verb) is known to be problematic at early stages of L1 acquisition; thus, only irreversible contexts were included in this task. Of the twenty-four contexts, twenty-three used regular participles (-ado,-ada, -ido, -ida), and only one context used an irregular participle (i.e., escrito 'written').

Although in principle all transitive verbs could be used in the passive voice, only transitive verbs that worked well with both copulas were used. This means that verbs that are lexicalized with either one of the copulas were not used. For instance, in (17), a verb such as tumbar works with ser, but the minimal pair with estar, in (18), has a meaning established by common use with the verb tumbar, denoting "to be lying down". This lexicalization makes the sentence with ser seem very odd.

$\begin{array}{lll}\text { 17. El hombre } & \begin{array}{l}\text { er-a } \\ \text { be-ser-IMPERFECT.SG }\end{array} & \begin{array}{l}\text { tumb-ado. } \\ \text { the man-M.SG }\end{array} \\ \text { "The man was knocked down." } & \\ \text { 18. } & \begin{array}{ll}\text { El hombre } \\ \text { the man-M.SG }\end{array} & \begin{array}{l}\text { tumb-ado. } \\ \text { "The man was lying down." }\end{array} \\ & \text { was-estar-IMPERFECT.SG } & \end{array}$




\section{Scripts and Token Sets}

The total number of sentences participants judged was 136, sixty-eight in each modality. There were one adjectival passive and one verbal passive for each of the twenty-four contexts. These forty-eight tokens were pseudorandomized in four scripts. Participants saw two of the four scripts: one script in the aural modality and another script in the written modality. Each script included four practice items, six tokens of adjectival passives, six tokens of verbal passives, twenty-four tokens of relative clauses (which were also investigated as part of a bigger study), and thirty-two fillers that were twelve simple active sentences, three simple sentences with estar, three simple sentences with ser, six passive clauses with fue, and eight relative clauses with plausible, non-reversible contexts (e.g., Ésta es la estrella que ven con el telescopio. "This is the star they see-PRESENT-PL with the telescope.") for a total of sixty-eight pseudorandomized items. See summary and examples in Table 2.

Table 2. Picture-matching task (PMT) sentences in each script (not including practice items).

\begin{tabular}{|c|c|}
\hline Type of Sentence & Example \\
\hline 6 verbal passive clauses & $\begin{array}{l}\text { La cena er-a serv-ida. } \\
\text { the dinner.F.SG. be-ser-IMPERFECT.SG serve-PTCP.F.SG } \\
\text { "Dinner was being served." }\end{array}$ \\
\hline 6 adjectival passive clauses & $\begin{array}{l}\text { La cena esta-ba serv-ida. } \\
\text { the dinner.F.SG. be-estar-IMPERFECT.SG serve-PTCP.F.SG } \\
\text { "Dinner was served." }\end{array}$ \\
\hline 12 simple active sentences & $\begin{array}{l}\text { La madre serv-ía la cena. } \\
\text { the mother serve-IMPERFECT.SG the dinner } \\
\text { "The mother served dinner." }\end{array}$ \\
\hline 3 simple sentences with estar & $\begin{array}{l}\text { Los libros esta-ban en el mostrador. } \\
\text { the books be-estar-IMPERFECT.PL on the counter } \\
\text { "The books were on the counter." }\end{array}$ \\
\hline 3 simple sentences with ser & $\begin{array}{l}\text { Er-a un libro. } \\
\text { be-ser-IMPERFECT.SG a book } \\
\text { "It was a book." }\end{array}$ \\
\hline 6 passive clauses with fue & $\begin{array}{l}\text { La mujer fue asesina-da por el criminal. } \\
\text { the woman be-ser-PRET.SG murder-PTCP.F.SG by } \\
\text { the criminal } \\
\text { "The woman was murdered by the criminal." }\end{array}$ \\
\hline 24 relative clauses & $\begin{array}{l}\text { Éste es el libro que cubri-ó las revistas. } \\
\text { this is the book that cover-PRET.SG the magazines } \\
\text { "This is the book that covered the magazines." }\end{array}$ \\
\hline 8 Fillers & $\begin{array}{l}\text { Éste es el coche que choc-ó la bicicleta. } \\
\text { this is the car that crash-PRET.SG the bicycle } \\
\text { "This is the car that crashed into the bicycle." }\end{array}$ \\
\hline
\end{tabular}

\section{PMT Procedure}

In the aural modality of the task, participants heard the sentences on headphones. The sentence was repeated twice. There was a pause of three seconds between the two sentences. Sentences were recorded by native speakers from Mexico and from Puerto Rico. Most PMT sentences were recorded by the Mexican speaker, and some were recorded by the Puerto Rican speaker. Sentences were controlled for prosodic cues that could lead the participant to choose a given answer by maintaining sentential stress on the first noun of the sentences. No pattern in terms of one speaker being favored over another was found.

Sentences in the written modality were presented in font size fourteen and white letters against a black background. Participants had eleven seconds to read the written 
sentences. ${ }^{3}$ Once participants read or heard the sentences, they could press any key to see the answer screen. The answer screen showed two $8^{\prime \prime} \times 5.5^{\prime \prime}$ drawings next to each other, which were labeled A and B. See Figure 1.

A

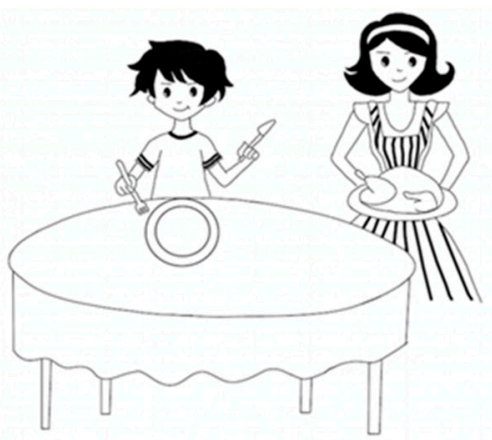

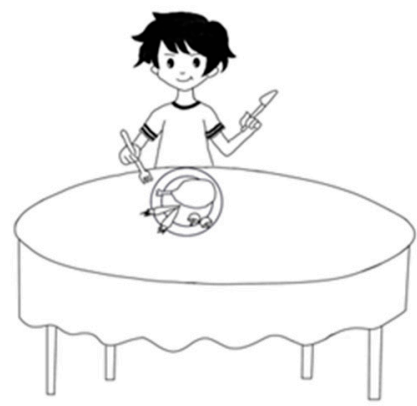

Figure 1. Picture-matching task (PMT) drawing.

Participants had to choose from these two drawings displayed on the screen: the one that matched the sentence they heard on the headphones or that they read on the screen. They had a maximum of ten seconds to choose an answer. They had to press the keyboard key labeled A or B, accordingly. Based on a U.S. keyboard layout, the labels A and B were placed on the letters $A$ and $L$ to reduce potential confusion given that the keys $A$ and $B$ are close to each other on the keyboard.

Accuracy was recorded for all experimental and filler sentences. Correct answers were assigned a score of 1 , and incorrect answers were assigned a score of 0 . An average of all answers was calculated. A mean score closer to 1 indicated better comprehension of these structures, and a mean score closer to 0 indicated poor comprehension of these structures.

\subsubsection{Grammaticality Judgment Task (GJT)}

The GJT was designed in the psycholinguistics software E-Prime 2.0 to assess acceptance of ser and estar in the imperfect tense. Acceptance of copulas in the imperfect would mean that in the PMT, inaccuracy in comprehension of passives with era and estaba are not due to low acceptance of era and estaba. Instead, accuracy in the PMT would reflect the participants' comprehension of the passive clauses.

\section{Scripts and Token Sets}

There was a total of 288 sentences (152 grammatical and 136 ungrammatical) divided into four pseudorandomized scripts. Two scripts were used in the aural modality and two were used in the written modality. Each GJT script consisted of four practice items-two grammatical and two ungrammatical sentences-and forty-six grammatical and ungrammatical sentences like those in Table 3. The complete list of experimental sentences appears in Appendix F. Filler sentences included simple sentences with and without subject verb inversion $(13 \mathrm{G}, 13 \mathrm{U})$. These sentences had $3^{\text {rd }}$-person singular and plural verbs in the preterite tense. Sentences were recorded by the same native speakers from Mexico and from Puerto Rico who recorded sentences for the PMT. Most GJT sentences were recorded by the Mexican speaker, and some were recorded by the Puerto Rican speaker. Sentences were controlled for prosodic cues that could lead the participant to choose a given answer by maintaining sentential stress on the first noun of the sentences. No pattern in terms of one speaker being favored over another was found.

3 Eleven seconds is the length of the longest sentence in the aural version of the PMT. 
Table 3. Grammaticality judgment task (GJT) sentences with copulas.

\begin{tabular}{|c|c|}
\hline Sentence Type & Example $^{1}$ \\
\hline 3 ser with unequivocal predicate, grammatical & $\begin{array}{l}\text { El cientifico er-a importante. } \\
\text { the scientist be-ser-IMPERFECT.SG important } \\
\text { "The scientist was important." }\end{array}$ \\
\hline $\begin{array}{l}3 \text { ser with unequivocal predicate, } \\
\text { ungrammatical }\end{array}$ & $\begin{array}{l}{ }^{*} \text { El científico esta-ba importante. } \\
\text { the scientist be-estar-IMPERFECT.SG important }\end{array}$ \\
\hline $\begin{array}{l}3 \text { estar with unequivocal predicate, } \\
\text { grammatical }\end{array}$ & $\begin{array}{l}\text { La madre esta-ba cansada. } \\
\text { the mother be-estar-IMPERFECT.SG tired. } \\
\text { "The mother was tired." }\end{array}$ \\
\hline $\begin{array}{l}3 \text { estar with unequivocal predicate, } \\
\text { ungrammatical }\end{array}$ & $\begin{array}{l}{ }^{*} \text { La madre er-a cansada. } \\
\text { the mother be } \text {-ser-IMPERFECT.SG tired }\end{array}$ \\
\hline 3 ser with prepositional phrase, grammatical & $\begin{array}{l}\text { La torre er-a de piedra. } \\
\text { the tower be-ser-IMPERFECT.SG of stone } \\
\text { "The tower was made out of stone." }\end{array}$ \\
\hline 3 ser with prepositional phrase, ungrammatical & $\begin{array}{l}\text { *La torre esta-ba de piedra. } \\
\text { the tower be } \text {-estar-IMPERFECT.SG of stone }\end{array}$ \\
\hline 3 estar with prepositional phrase, grammatical & $\begin{array}{l}\text { Los hombres esta-ban en el trabajo. } \\
\text { the men be-estar-IMPERFECT.PL in the work } \\
\text { "The men were at work." }\end{array}$ \\
\hline $\begin{array}{l}3 \text { estar with prepositional phrase, } \\
\text { ungrammatical }\end{array}$ & $\begin{array}{l}\text { *Los hombres er-an en el trabajo. } \\
\text { the men be-ser-IMPERFECT.SG at work }\end{array}$ \\
\hline 3 present progressive, grammatical & $\begin{array}{l}\text { El avión esta-ba aterrizando. } \\
\text { the plane be-estar-IMPERFECT.SG landing. } \\
\text { "The plane was landing." }\end{array}$ \\
\hline 3 present progressive, ungrammatical & $\begin{array}{l}\text { *El avión er-a aterrizando. } \\
\text { the plane be-ser-IMPERFECT.SG landing }\end{array}$ \\
\hline $\begin{array}{l}6 \text { verbal passives with ser and displaced agent, } \\
\text { grammatical }\end{array}$ & $\begin{array}{l}\text { La cena er-a servida por los meseros. } \\
\text { the dinner be -ser-IMPERFECT.SG serve-PTCP.M.SG } \\
\text { by the waiters. } \\
\text { "Dinner was served by the waiters." }\end{array}$ \\
\hline $\begin{array}{l}6 \text { adjectival passives with estar and displaced } \\
\text { agent, ungrammatical }^{2}\end{array}$ & $\begin{array}{l}{ }^{*} \text { La cena esta-ba serv-ida por los meseros. } \\
\text { the dinner be -estar-IMPERFECT.SG serve-PTCP.M.SG } \\
\text { by the waiters. }\end{array}$ \\
\hline 3 canonical passives with fue, grammatical & $\begin{array}{l}\text { La paciente fue examin-ada por el médico. } \\
\text { the patient be-ser-PRET.SG examine-PTCP.F.SG by } \\
\text { the doctor. } \\
\text { "The patient was examined by the doctor." }\end{array}$ \\
\hline
\end{tabular}

\footnotetext{
${ }^{1}$ English translation provided for grammatical items only. ${ }^{2}$ For coding purposes, we considered all these sentences ungrammatical. For details about the (un)grammaticality of adjectival sentences with a by-phrase, see Gehrke and Marco (2014), García-Pardo (2017) and Varela (1992).
}

Although the list of simple sentences labeled copula "with unequivocal predicate" included mostly unequivocal adjectival predicates for each copula, it also included predicates that expressed identity and membership. We were cautious not to include predicates to which the use of estar is known to have expanded (e.g., Bueno "good", malo "bad", bonito "pretty", chiquito "small/little", chaparrito "short", simpática "likeable", nuevo "new", tranquilo "calm", etc. (Silva-Corvalán 1986; Brown and Cortés-Torres 2012).

\section{GJT Procedure}

In the aural modality of the task, participants listened to the sentences on headphones. Each sentence was repeated twice with a three-second pause in between. Grammatical and ungrammatical sentences were controlled for prosodic cues that could lead the participant to choose a given answer by maintaining sentential stress on the first verb or noun of the 
sentence. Sentences in the written modality were presented in font size fourteen and white letters against a black background. Participants had thirteen seconds to read the written sentences. ${ }^{4}$ Once participants listened to or read the sentences, they could press any key to see the answer screen. They had ten seconds to choose an answer by pressing the key labeled " $\mathrm{A}$ " for correct sentences, and the key labeled " $\mathrm{F}$ ", for incorrect sentences. The choices " $\mathrm{A}$ " and " $\mathrm{F}$ " were explained to the participants as a grade system: choose " $\mathrm{A}$ " if the sentence does not have any errors. If it has an error, "fail" the sentence by giving it an " $\mathrm{F}$ ".

Accuracy was recorded for all sentences. Correct answers were assigned a score of one, and incorrect answers were assigned a score of zero. An average of all answers was calculated.

We also evaluated the acceptance of verbal passives with a displaced agent, which would indicate that speakers know that these sentences allow an agent introduced by the preposition por. Adjectival passives with the displaced agent are even less frequent than verbal passives and are ungrammatical with definite agents (Gehrke and Marco 2014), as the sentences used in our study. For the present study, only results of verbal passives are relevant.

Verbal passives with ser in the imperfect tense are not taught and are not frequent in the input; thus, testing the acceptance of verbal passives with fue, the canonical past tense, would indicate whether participants were familiar with the structure of verbal passives. Higher acceptability ratings on verbal passives with the preterite would indicate knowledge of the syntax of passives (see also Bruhn de Garavito and Valenzuela (2008) and Valenzuela et al. (2015)). If participants do not accept the verbal passive with the copula in the preterite (fue), they are expected to be even less accepting of the passive with the copula in the imperfect (era).

Simple sentences with copula and unequivocal adjectival predicates are very hard for L2 learners, because in some cases, the meaning of the adjective changes depending on the copula (Geeslin and Guijarro-Fuentes 2006). Although HL learners have been reported to extend the distribution of estar with predicate adjectives in cases where ser is typically used, they seem to acquire early on the semantic distinction between the copulas (Silva-Corvalán 1994, 2014). The simple sentences with ser and estar in the GJT should confirm that this is the case.

Simple sentences with ser in the present tense with unequivocal prepositional phrases with the preposition de referring to origin (Él es de San Juan, "He is from San Juan"), possession (Es de María, "That is María's") and composition (La mesa es de madera "The table is made of wood") are acquired relatively early by L2 learners (Briscoe 1995; Geeslin 2013). Sentences with estar and the unequivocal prepositional phrase en + location (Está en San Juan, "She/He is in San Juan.") are acquired later (Geeslin 2003; VanPatten 1987). These sentences were included to test basic knowledge of the imperfect tense and of copula use in Spanish. Even though HL learners have extended the distribution of use of the copula estar, research shows that they know the syntactic distribution of the copulas with different prepositional phrases (Silva-Corvalán 2014, p. 251). Thus, HL learners are expected to be accurate judging these sentences.

Simple sentences with estar as an auxiliary in the present progressive are a relatively frequent construction in Spanish and L2 learners acquire this structure after at least two years of Spanish instruction. HL learners by age five still show robust knowledge of this structure (Silva-Corvalán 2014; Geeslin 2013); thus, all participants were expected to be highly accurate with it.

\section{Results}

Data were analyzed with StatPlus:mac Pro Version v7 (AnalystSoft Inc. 2019) and with a mixed effects logistic regression using the 'glmer' command from the 'lme4'package

413 seconds is the length of the longest sentence in the aural version of the GJT. 
(Bates et al. 2015) in R (R-Core-Team 2019). Maximal mixed-effects models included crossed random effects for subjects and items when convergence was possible, following Barr et al. (2013). Although we included a comparison group of MRNS that served to obtain a measure of grammaticality judgments and comprehension of the target construction included in our study, only L2 learners and HL learners were included in the analyses because the focus of this study is the differences and similarities between these two bilingual groups. $p$-values less than 0.05 were considered significant. All participants entered an answer within the allotted time for each item in the PMT and the GJT tasks; therefore, all answers were included in the analysis.

Before presenting PMT results for the comprehension of passives, we will present results of the GJT that will show whether participants accepted copulas in the imperfect tense, full verbal passives with fue, and full verbal passives with era.

\subsection{GJT}

The GJT was designed to assess participants' acceptance of the ser and estar in the imperfect tense. For this purpose, simple sentences with era and estaba with unequivocal predicates were created. Figures 2 and 3 display the mean accuracy scores on grammatical and ungrammatical sentences with ser + unequivocal predicate, estar + unequivocal predicate, estar + unequivocal prepositional phrase, ser + unequivocal prepositional phrase and with copulas + present progressive. High acceptance of copulas in the imperfect tense in the GJT but low accuracy in the comprehension of passives in the PMT would indicate that participants accept copulas in the imperfect tense in simple sentences, but they do not understand the meaning they express in the passives. Accuracy scores for monolingually raised native speakers are shown in the figures to provide the reader with visual information on how different sentences are accepted.

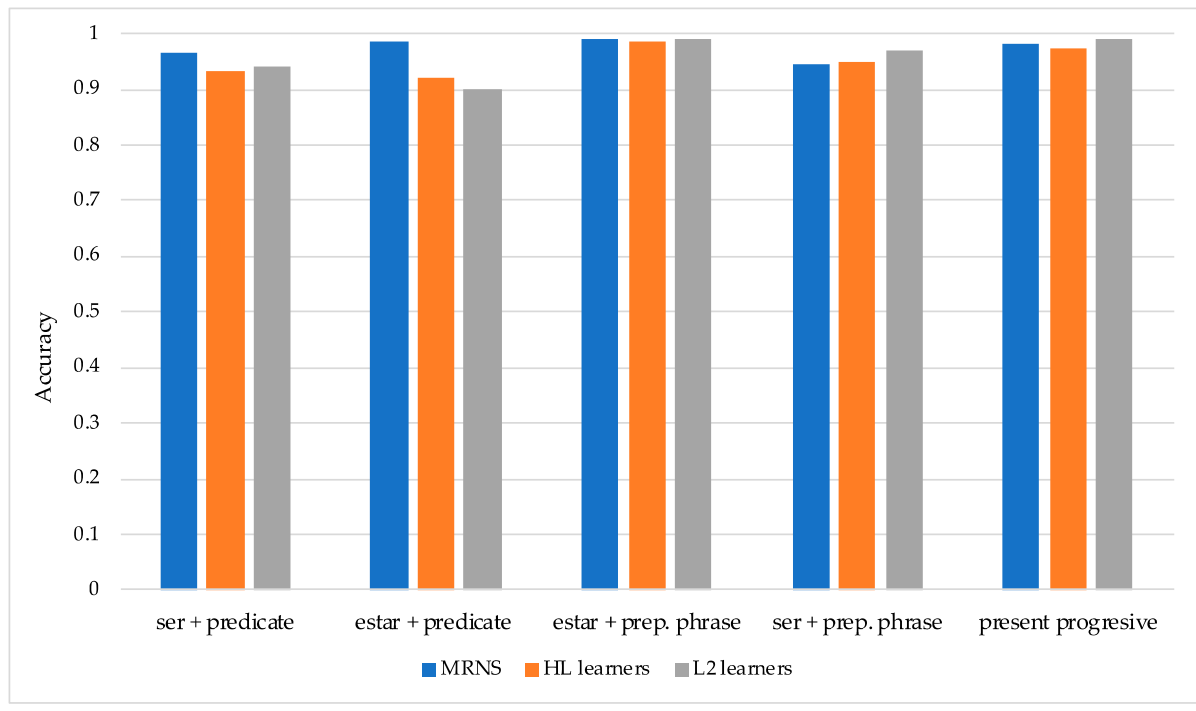

Figure 2. GJT: Mean accuracy ratings on grammatical sentences. 


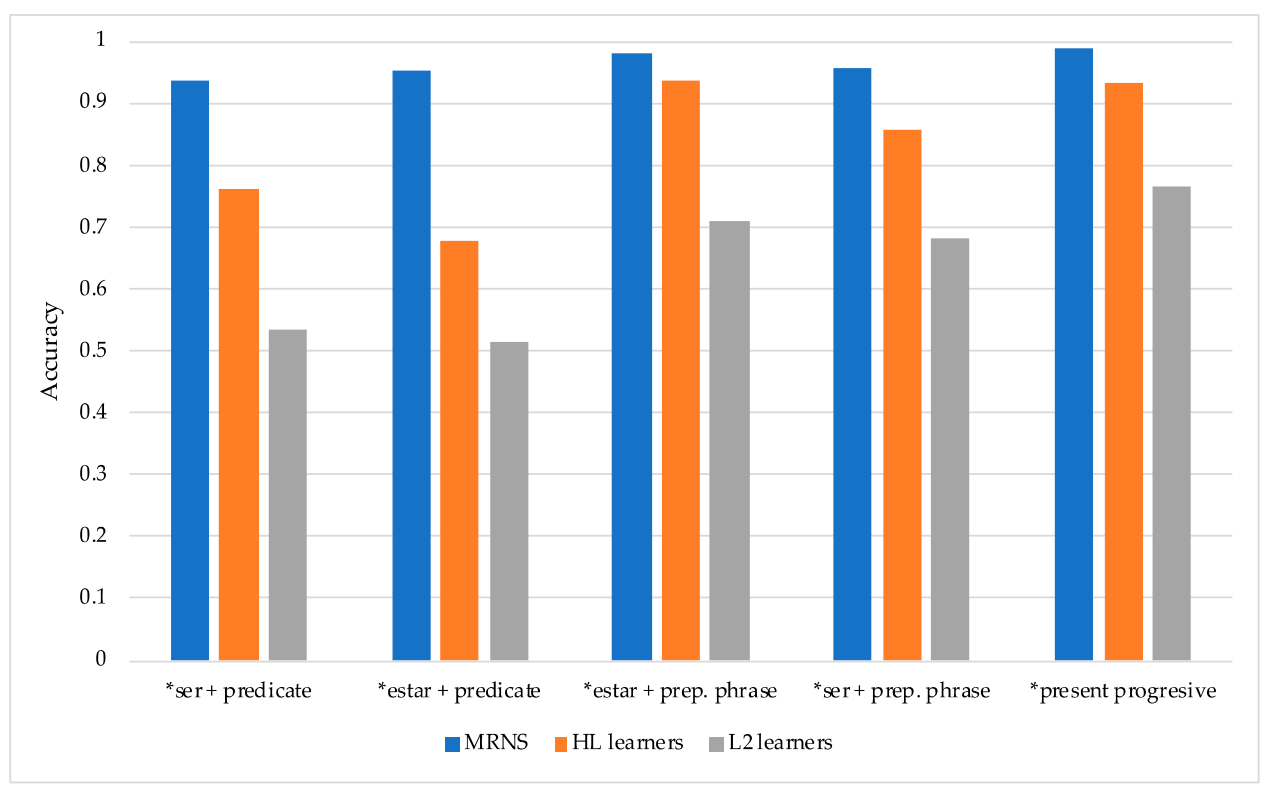

Figure 3. GJT: Mean accuracy ratings on ungrammatical sentences.

The mean accuracy scores for grammatical sentences were $0.97(\mathrm{SD}=0.03)$ for MRNS, for L2 learners, $0.96(\mathrm{SD}=0.05)$, and for HL learners, $0.97(\mathrm{SD}=0.06)$. Mean accuracy scores for ungrammatical sentences were $0.96(\mathrm{SD}=0.06)$ for MRNS, $0.64(\mathrm{SD}=0.31)$ for L2 learners, and for HL learners, $0.83(\mathrm{SD}=0.15)$. Figures 2 and 3 show data by type of sentence. ${ }^{5}$

For ungrammatical sentences, ten L2 learners' mean scores were below 0.60 , whereas only one HL learner scored below 0.60. Lower mean scores for ungrammatical sentences were expected because of the learners' tendency to accept ungrammatical sentences (Polinsky 2016).

We analyzed the accuracy of HL and L2 learners with grammatical and ungrammatical sentences with a Generalized Linear Mixed Model (GLMM) that included the dependent variable accuracy, (binary outcome 1 or 0 ), analyzed as a function of grammaticality (grammatical, ungrammatical), group (HL learners, L2 learners), and modality (aural, written) as fixed effects, with random intercepts for subjects and items, and by-subject and by-item random slopes for grammaticality. See Table 4 .

Table 4. Parameter estimates for second language (L2) and heritage language (HL) learners' accuracy with (un)grammatical sentences.

\begin{tabular}{ccccccc}
\hline & \multicolumn{3}{c}{ Fixed Effects } & & & \multicolumn{2}{c}{ Random Effects } \\
\cline { 5 - 7 } Parameters & Estimate & $S E$ & $z$ & $p$ Value & SD & SD \\
\hline Intercept & 3.943 & 0.347 & 11.364 & $<0.001$ & 1.072 & 0.806 \\
Ungrammatical & -2.116 & 0.397 & -5.338 & $<0.001$ & 2.101 & 1.007 \\
Group L2 & -0.548 & 0.330 & -1.663 & 0.096 & - & - \\
Modality W & 0.298 & 0.120 & 2.492 & 0.013 & - & - \\
\hline
\end{tabular}

The analysis shows that the odds of learners' accurate answers for ungrammatical sentences are $\mathrm{e}^{2.116} \approx 8.30$ times lower than the odds for grammatical sentences (estimate $=-2.116, S E=0.347, z=-5.338, p<0.001$ ). The difference between HL and L2 learners in mean accuracy scores for all (grammatical and ungrammatical) sentences was not

5 One of the 12 simple sentences with estar inadvertently included an adjectival passive with the irregular participle rotas. The grammatical and ungrammatical items with this participle were excluded from analysis. 
significant. The odds of learners' accurate answers for items in the written modality are $\mathrm{e}^{0.298}=1.35$ times higher than the odds for the aural modality (estimate $=0.298, S E=0.120$, $z=2.492, p=0.013$ ). The model failed to converge when interactions between fixed effects were included.

Given the discrepancy in accuracy for ungrammatical sentences, we focused on L2 and HL learners' mean accuracy scores for ungrammatical sentences; see Table 5. We analyzed HL and L2 learners' accuracy scores for ungrammatical sentences with a GLMM that included the dependent variable accuracy (binary outcome 1 or 0 ), analyzed as a function of group (HL learners vs. L2 learners) and modality (aural, written) as a fixed effect, with random intercepts for subjects and items and by-subject random slopes for modality. The odds of accurate answers with ungrammatical sentences for L2 learners are $\mathrm{e}^{1.762}=5.82$ times lower than the odds for HL learners (estimate $=-1.762, S E=0.479$, $z=-3.677, p<0.001)$. The odds of learners' accurate answers for items in the written modality are $\mathrm{e}^{0.695}=2.00$ times higher than the odds for the aural modality (estimate $=$ $0.695, S E=0.175, z=3.972, p<0.001$ ). The model failed to converge when the interaction between group and modality was included.

Table 5. Parameter estimates for L2 and HL learners' accuracy with ungrammatical sentences.

\begin{tabular}{ccccccc}
\hline & \multicolumn{3}{c}{ Fixed Effects } & & & \multicolumn{2}{c}{ Random Effects } \\
\cline { 5 - 7 } & & & & & By Subject & By Items \\
\hline Parameters & Estimate & $S E$ & $z$ & $p$ Value & SD & SD \\
\hline Intercept & 2.279 & 0.364 & 6.265 & $<0.001$ & 1.689 & 1.089 \\
Group L2 & -1.762 & 0.479 & -3.677 & $<0.001$ & - & - \\
Modality W & 0.695 & 0.175 & 3.972 & $<0.001$ & 0.652 & - \\
\hline
\end{tabular}

To investigate further the source of higher accuracy in the written modality, learners' performance by modality for each group was compared using a paired sample-t-test. HL learners' mean accuracy scores for aural and written modality were $0.89(\mathrm{SD}=0.09)$ and $0.89(\mathrm{SD}=0.10)$, respectively, and there was no significant difference between the two, $t(32)=0.04, p=0.969$. However, L2 learners' mean accuracy scores for aural and written modality were $0.77(\mathrm{SD}=0.17)$ and $0.82(\mathrm{SD}=0.17)$, respectively, and this difference was significant, $t(30)=2.79, p=0.009$.

The GJT also investigated accuracy with verbal passives with the canonical past tense fue and with the copula in the imperfect tense era; see Figure 4.

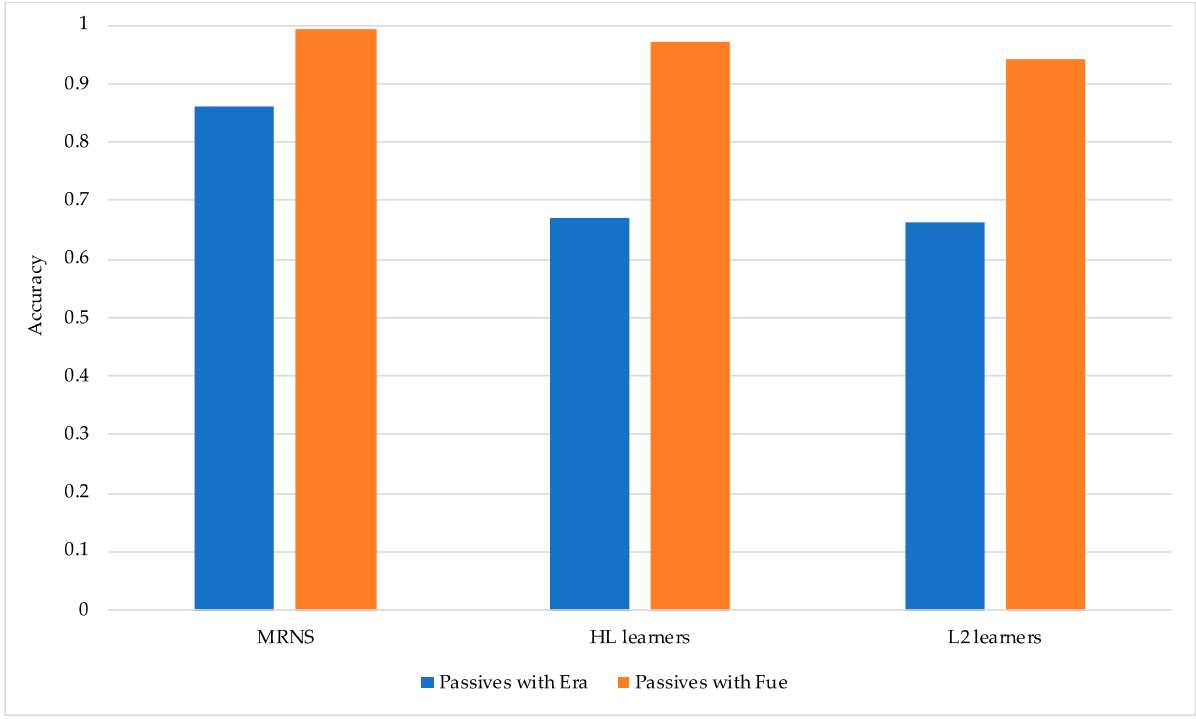

Figure 4. GJT: Mean accuracy ratings on grammatical passives with era and fue. 
We analyzed the accuracy of HL and L2 learners with grammatical passives with fue and era with a GLMM that included the dependent variable accuracy (binary outcome 1 or 0 ) analyzed as a function of group (HL learners, L2 learners) and condition (passive with fue, passive with era) as fixed effects, with random intercepts for subjects and items, and by-subject random slopes for condition; see Table 6 .

Table 6. Parameter estimates for HL and L2 learners' accuracy with grammatical passives with era and fue.

\begin{tabular}{ccccccc}
\hline & \multicolumn{3}{c}{ Fixed Effects } & & & \multicolumn{2}{c}{ Random Effects } \\
\cline { 5 - 7 } & & & & & By Subject & By Items \\
\hline Parameters & Estimate & $S E$ & $z$ & $p$ Value & SD & SD \\
\hline Intercept & 1.013 & 0.288 & 3.516 & $<0.001$ & 1.431 & 0.391 \\
Group L2 & -0.043 & 0.377 & -0.113 & 0.910 & - & - \\
Condition Fue & 3.063 & 0.629 & 4.874 & $<0.001$ & 1.704 & - \\
\hline
\end{tabular}

The analysis shows that the odds of learners' accurate answers for passives with fue are $\mathrm{e}^{3.063} \approx 21.40$ times higher than the odds for verbal passives with era (estimate $=$ 3.063, $S E=0.629, z=4.874, p<0.001)$. This difference was significant. Thus, consistent with previous studies (Bruhn de Garavito and Valenzuela 2008; Valenzuela et al. 2015), L2 learners and HL learners found the verbal passive with era less acceptable than verbal passives with fue.

In sum, although ten L2 learners' and one HL learner's scores for ungrammatical sentences were below 50\% accuracy, results of the GJT show that most participants accept copulas in the imperfect tense in different simple contexts and verbal passives with fue more than verbal passives with era. Thus, low accuracy in the comprehension of passives in the PMT would indicate that participants do not understand the meaning the copulas express in the passives.

\subsection{Picture Matching Task}

Figure 5 shows mean percentage accuracy on the comprehension of adjectival and verbal passives. Mean accuracy scores for the adjectival passives were $0.97(\mathrm{SD}=0.05)$ for MRNS, $0.92(\mathrm{SD}=0.15)$ for HL learners, and $0.80(\mathrm{SD}=0.24)$ for L2 learners. Mean accuracy scores for the verbal passives with era were $0.90(\mathrm{SD}=0.11)$ for MRNS, $0.38(\mathrm{SD}=0.31)$ for HL learners, and $0.20(\mathrm{SD}=0.22)$ for L2 learners, as shown in Figure 5. Accuracy scores for monolingually raised native speakers are shown to inform the reader that the relevant sentences were comprehended by these speakers as a control measure.

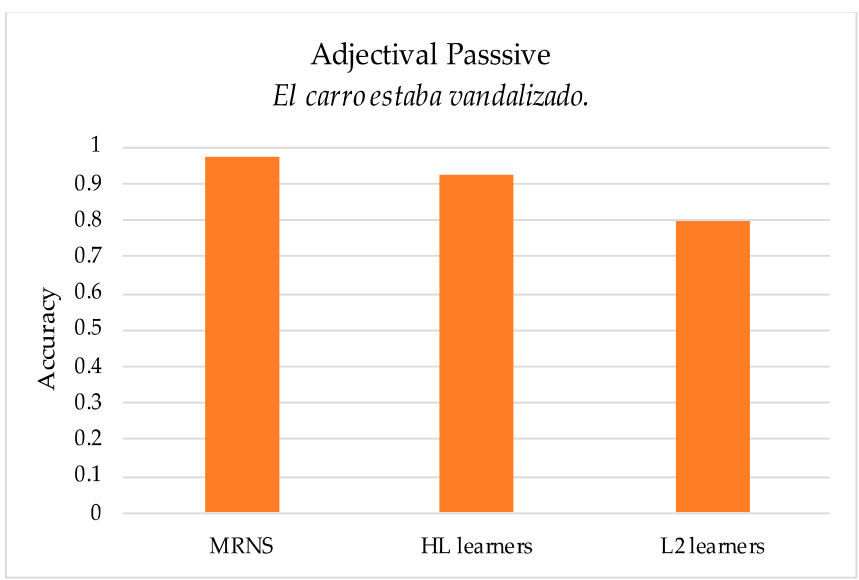

Figure 5. PMT: Mean accuracy on adjectival and verbal passives. 
These data were analyzed with mixed effects logistic regression using the 'glmer' command from the 'lme4'package (Bates et al. 2015) in R (R-Core-Team 2019). Maximal mixed-effects models included crossed random effects for subjects and items when convergence was possible, following Barr et al. (2013). Only learner groups were included in the analyses. A fixed effect was considered significant if the $p$ value was lower than 0.05 .

We analyzed the accuracy of HL and L2 learners on the comprehension of adjectival and verbal passives with a GLMM that included the dependent variable accuracy (binary outcome 1 or 0 ), analyzed as a function of passive type (adjectival, verbal) and group (HL learners, L2 learners) as fixed effects, with random intercepts for subjects and items, and by-subject and by-item random slopes for condition. The results are presented in Table 7 .

Table 7. Parameter estimates for L2 and HL learners' comprehension of adjectival and verbal passives.

\begin{tabular}{ccccccc}
\hline & \multicolumn{3}{c}{ Fixed Effects } & & & \multicolumn{2}{c}{ Random Effects } \\
\cline { 5 - 7 } & & & & & By Subject & By Items \\
\hline Parameters & Estimate & $S E$ & $z$ & $p$ Value & SD & SD \\
\hline Intercept & -0.709 & 0.307 & -2.305 & 0.021 & 1.670 & 0.480 \\
Adjectival Passive & 4.283 & 0.465 & 9.210 & $<0.001$ & 2.713 & 0.224 \\
Group L2 & -1.398 & 0.346 & -4.044 & $<0.001$ & - & - \\
\hline
\end{tabular}

The odds of accurate answers for adjectival passives are $\mathrm{e}^{4.283} \approx 72.43$ times higher than the odds for verbal passives (estimate $=4.283, S E=0.465, z=9.210, p<0.001$ ). The odds of L2 learners being accurate with these clauses are $\mathrm{e}^{1.398} \approx 4.05$ times lower than those of HL learners (estimate $=1.398, S E=0.346, z=-4.044, p<0.001$ ). The main effects of group and type of passive were highly significant. The model did not converge when interaction between group and type of passive was included.

\subsubsection{L2 learners}

Figure 6 shows the L2 learners' mean accuracy scores for comprehension of passives in the aural and written modality, which were $0.48(\mathrm{SD}=0.16)$ and $0.51(\mathrm{SD}=0.16)$.

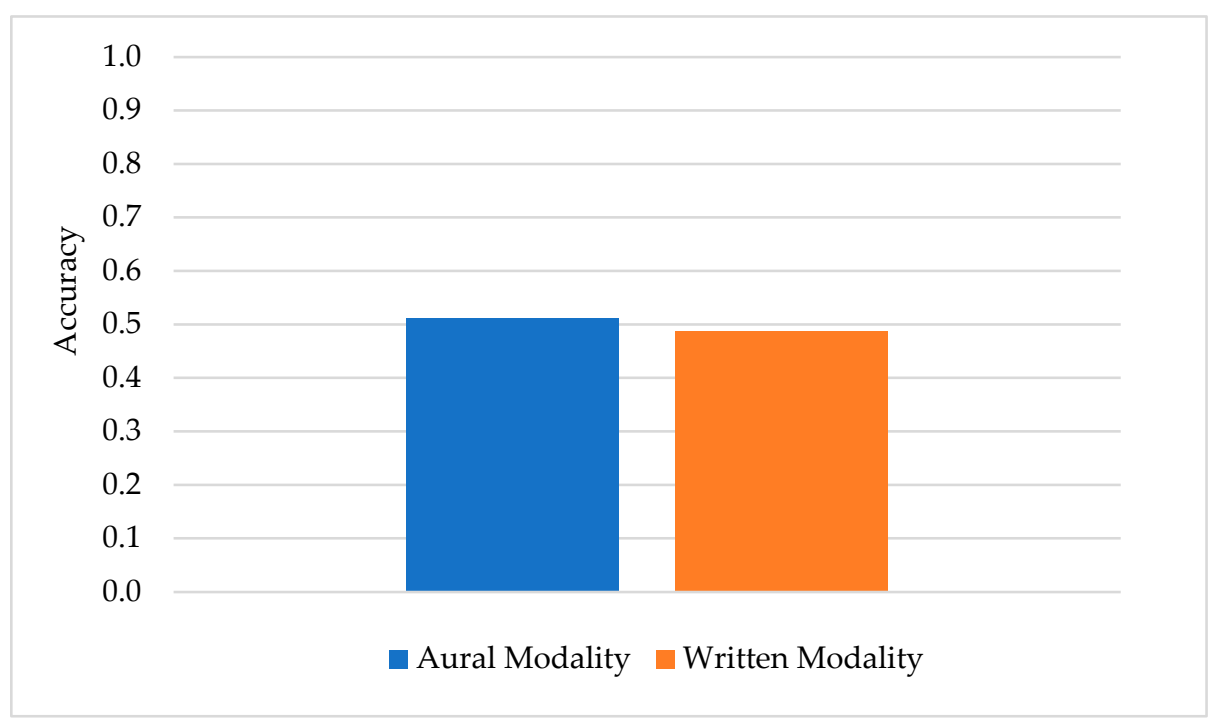

Figure 6. PMT: L2 learners' mean accuracy on comprehension of passive clauses by modality.

Figure 7 shows the number of Spanish courses completed by L2 learners at time of testing, which were on average $14.1(\mathrm{SD}=9.43)$. 


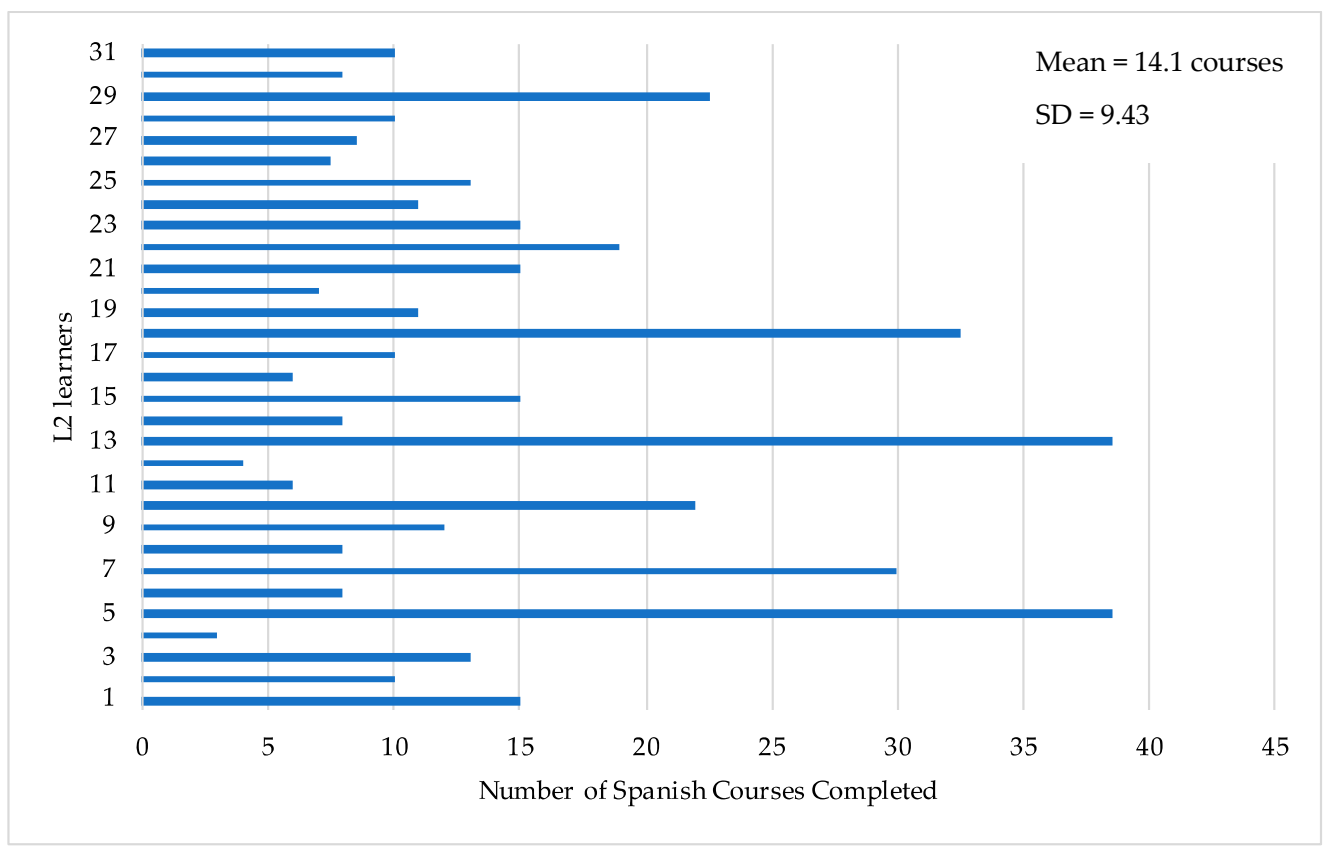

Figure 7. Number of Spanish courses completed by the L2 learners of Spanish.

L2 learners' model for modality and instruction effects included the dependent variable accuracy (binary outcome 1 or 0 ), which was analyzed as a function of condition (type of passive), modality, instruction, and the interaction between instruction and modality as fixed effects, with random intercepts for subjects and items, and by-subject random slopes for condition; see Table 8 . The model did not converge when interaction between type of passive and instruction was included.

Table 8. Parameter estimates for L2 learners' comprehension of passives by modality and instruction.

\begin{tabular}{ccccccc}
\hline & \multicolumn{3}{c}{ Fixed Effects } & & & \multicolumn{2}{c}{ Random Effects } \\
\cline { 5 - 7 } & & & & & By Subject & By Items \\
\hline Parameters & Estimate & $S E$ & $z$ & $p$ Value & SD & SD \\
\hline Intercept & -1.835 & 0.370 & -4.954 & $<0.001$ & 1.438 & 0.565 \\
Adjectival Passive & 4.056 & 0.620 & 6.540 & $<0.001$ & 2.702 & - \\
Modality W & -0.217 & 0.220 & -0.984 & 0.325 & - & - \\
Instruction & 0.490 & 0.242 & 2.026 & 0.043 & - & - \\
Mod*Inst $^{1}$ & -0.105 & 0.252 & -0.416 & 0.678 & - & -
\end{tabular}

1 "Mod*Inst" is the interaction between modality and instruction.

The main effect of modality in the comprehension of passive clauses by L2 learners was not significant. L2 learners' odds of being more accurate with adjectival passive clauses were $\mathrm{e}^{4.056} \approx 57.71$ times the odds of being accurate with verbal passives (estimate $=4.056$, $S E=0.620, z=6.540, p<0.001)$, and there was a significant main effect of instruction (estimate $=0.490, S E=0.242, z=2.026, p=0.043$ ). Therefore, the L2 learners with more instruction were more likely to be accurate with these clauses. The interaction between modality and instruction was not significant (estimate $=-0.105, S E=0.252, z=-0.416$, $p=0.678)$.

Data from oral and written proficiency measures were collected to find out whether proficiency affected the comprehension of these clauses. From all proficiency measures collected (i.e., DELE, MLU, MATTR, Fluency), model convergence was achieved with DELE, MLU, and MATTR data. This model included the dependent variable accuracy (binary outcome 1 or 0 ), analyzed as a function of condition (type of passive), one scaled proficiency measure (DELE, MATTR, or MLU) as a fixed effect, subject and item as random 
effects with intercepts included, and by-subject random slopes for condition. When random slopes for items were added, the model did not converge.

The main effects of DELE, MATTR, and MLU were not significant in the comprehension of these clauses, as shown in Table 9. These proficiency measures were scaled. Please note that in Table 9, the Intercept's Estimate, $S E, z$, and $p$ value and the Adjectival Passive's Estimate, $S E, z$ and $p$ value corresponds to the model for DELE. Since MATTR and MLU values for Estimate, $S E, z$, and $p$ value were very similar to those of DELE, they were not included in separate tables.

Table 9. Parameter estimates for L2 learners' comprehension of passives by proficiency.

\begin{tabular}{|c|c|c|c|c|c|c|}
\hline \multirow{2}{*}{\multicolumn{5}{|c|}{ Fixed Effects }} & \multicolumn{2}{|c|}{ Random Effects } \\
\hline & & & & & By Subject & By Items \\
\hline Parameters & Estimate & $S E$ & $z$ & $p$ Value & SD & SD \\
\hline Intercept & -1.985 & 0.379 & -5.235 & $<0.001$ & 1.564 & 0.566 \\
\hline Adjectival Passive & 4.023 & 0.610 & 6.600 & $<0.001$ & 2.657 & - \\
\hline DELE & 0.294 & 0.218 & 1.349 & 0.177 & - & - \\
\hline MATTR & 0.218 & 0.195 & 1.116 & 0.264 & - & - \\
\hline MLU & -0.116 & 0.202 & -0.572 & 0.567 & - & - \\
\hline Fluency & - & - & - & - & - & - \\
\hline
\end{tabular}

\subsubsection{HL Learners}

HL learners' mean accuracy score for passives in the written modality was 0.62 $(\mathrm{SD}=0.20)$, and in the aural modality, it was $0.68(\mathrm{SD}=0.19)$, as shown in Figure 8.

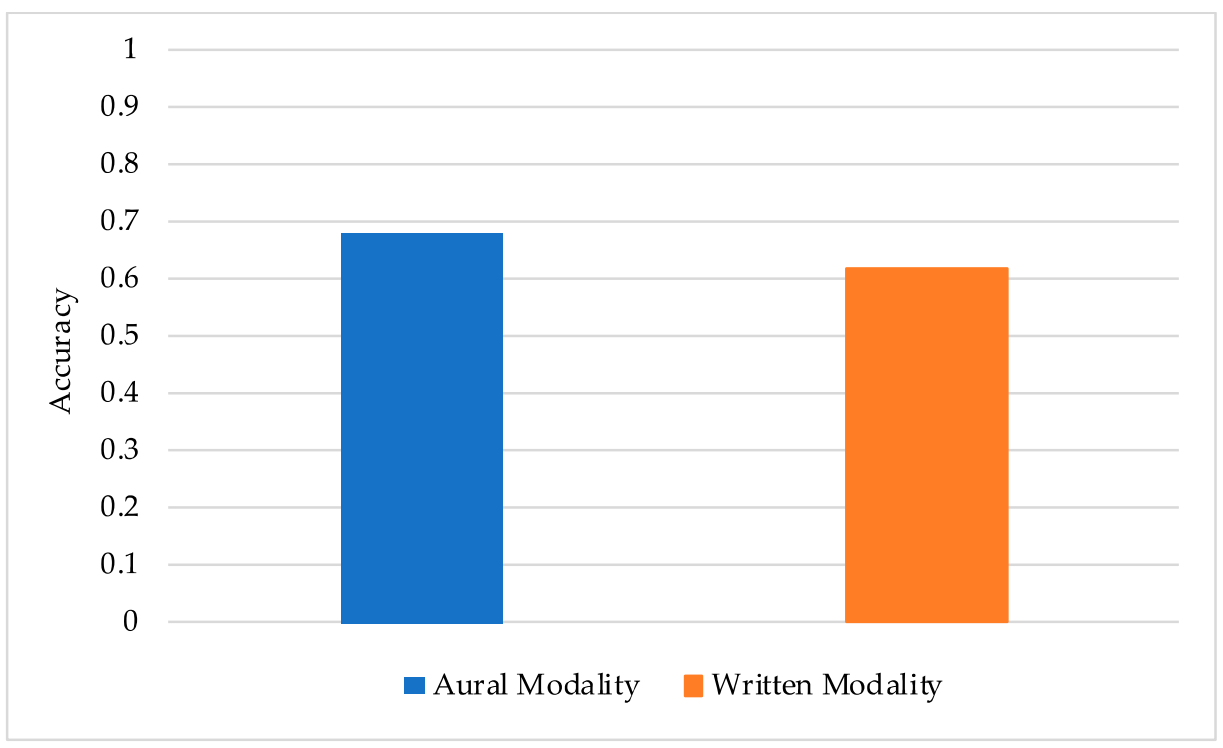

Figure 8. PMT: HL learners' mean accuracy on comprehension of passive clauses by modality.

Figure 9 shows that the mean HL learners' Spanish instruction was 8.17 courses $(\mathrm{SD}=7.95)$. 


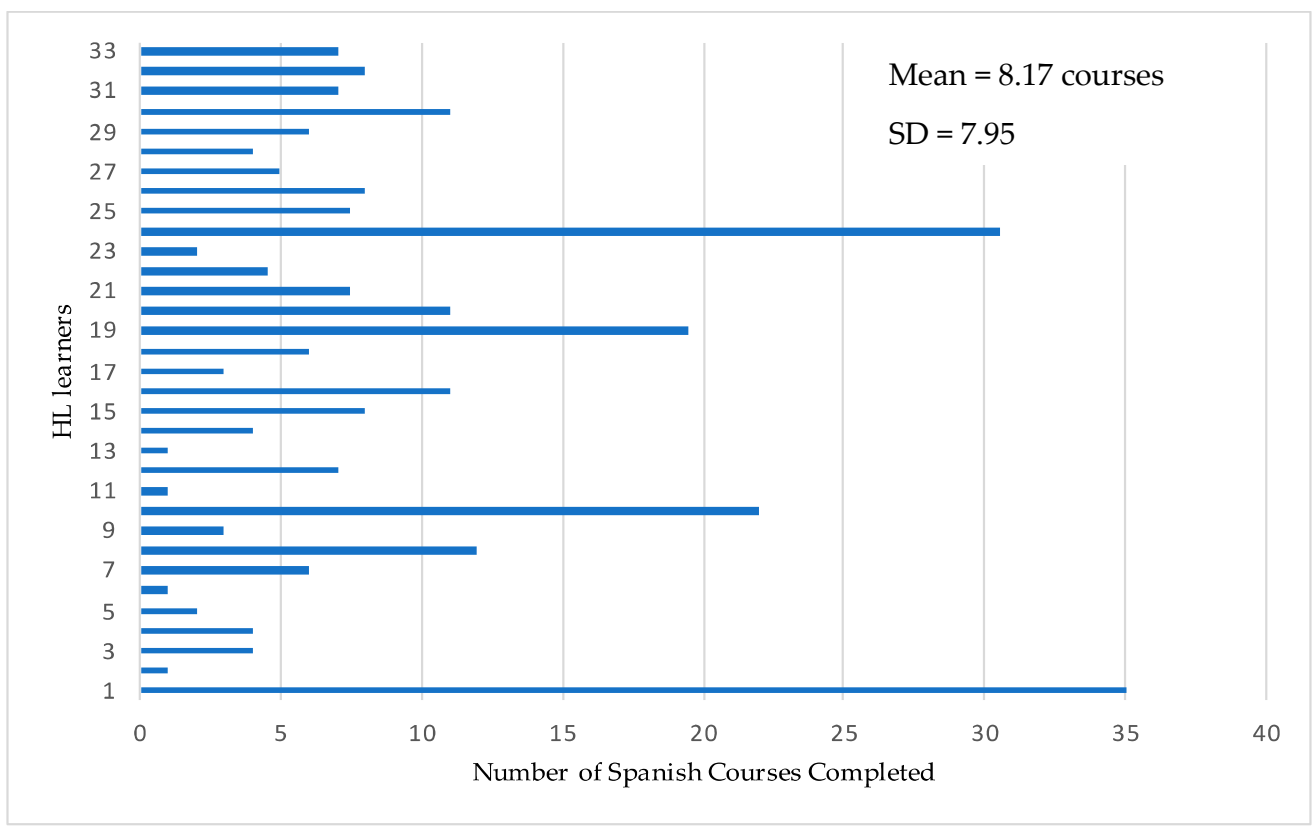

Figure 9. Number of Spanish courses completed by the HL learners.

The HL learners' model for modality effects in the comprehension of passives included the dependent variable accuracy (binary outcome 1 or 0 ) analyzed as a function of condition (type of passive), modality, and instruction as fixed effects, with random intercepts for subjects and items, and by-subject and by-item random slopes for condition. Modality was coded using contrast coding, -0.5 for aural modality, and 0.5 for written modality. When instruction was added to the model, the model did not allow by-items random slopes for condition. The model did not converge when interactions between the fixed effects was included. Table 10 shows the parameter estimates.

Table 10. Parameter estimates for HL learners 'comprehension of passives by modality and instruction.

\begin{tabular}{ccccccc}
\hline & \multicolumn{3}{c}{ Fixed Effects } & & & \multicolumn{2}{c}{ Random Effects } \\
\cline { 5 - 7 } & & & & & By Subject & By Items \\
\hline Parameters & Estimate & $S E$ & $z$ & $p$ Value & SD & SD \\
\hline Intercept & -0.796 & 0.371 & -2.144 & 0.032 & 1.898 & 0.241 \\
Adjectival Passive & 4.740 & 0.795 & 5.964 & $<0.001$ & 2.816 & 0.241 \\
Modality & -0.613 & 0.230 & -2.666 & 0.008 & - & - \\
Instruction & 0.016 & 0.037 & 0.448 & 0.654 & - & - \\
\hline
\end{tabular}

The main effect of modality in the comprehension of passives by HL learners was significant, as shown in Table 10. HL learners' odds of accurate answers for aural modality were $\mathrm{e}^{0.6130} \approx 1.85$ times higher than the odds for written modality (estimate $=-0.613$, $S E=0.230, z=-2.67, p=0.008)$. HL learners' odds of being more accurate with adjectival passives were $\mathrm{e}^{4.7401} \approx 114.45$ times higher than the odds of being accurate with verbal passives (estimate $=4.740, S E=0.795, z=5.964, p=<0.001$ ). The main effect of instruction was not significant (estimate $=0.016, S E=0.037, z=0.448, p=0.654$ ). 
To find out whether proficiency accounted for the comprehension of passives, a model for each measure (DELE, MATTR, MLU, or Fluency) was created and analyzed. The model for each proficiency measure included the dependent variable accuracy (binary outcome 1 or 0 ), analyzed as a function of condition, modality (contrast coded, aural $=-0.5$, written $=0.5$ ), and one proficiency measure (either DELE, MATTR, MLU or Fluency) as fixed effects, and subject and item as random effects with intercepts included, and by-subject random slopes for condition. When random slopes for items were added, the model did not converge. Table 11 summarizes the parameter estimates. Only the main effects of DELE and MLU were significant ( $p=0.017, p=0.018$, respectively). Thus, both proficiency measures emerged as significant predictors of comprehension of passive clauses.

Table 11. Parameter estimates for HL learners' comprehension of passive clauses by proficiency.

\begin{tabular}{ccccccc}
\hline & \multicolumn{2}{c}{ Fixed Effects } & & & \multicolumn{2}{c}{ Random Effects } \\
\cline { 3 - 7 } & & & & & By Subject & By Items \\
\hline Parameters & Estimate & $S E$ & $\boldsymbol{p}$ Value & SD & SD \\
\hline Intercept & -0.796 & 0.355 & -2.219 & 0.027 & 1.828 & 0.163 \\
Adjectival Passive & 4.652 & 0.750 & 6.204 & $<0.001$ & 2.839 & - \\
Modality & -0.610 & 0.230 & -2.655 & 0.008 & - & - \\
DELE & 0.614 & 0.257 & 2.389 & 0.017 & - & - \\
MLU & 0.673 & 0.285 & 2.360 & 0.018 & - & - \\
MATTR & 0.462 & 0.288 & 1.605 & 0.108 & - & - \\
Fluency & 0.468 & 0.288 & 1.628 & 0.104 & & -
\end{tabular}

Even though heritage speakers performed significantly more accurately in the comprehension of verbal passives than the L2 learners, their performance was below $50 \%$ accuracy. The frequency distribution shows that from the thirty-three HL learners, twelve scored between 0.58 and 1.00 . That is, $64 \%$ of participants scored 0.50 or below. This contrasts with the distribution of L2 learners that shows $94 \%$ of participants $(n=30)$ scoring 0.50 or below.

Interestingly, the only HL learner whose mean score for ungrammatical sentences was below chance obtained a mean score for 0.58 for verbal passives and of 1.00 for adjectival passives. The ten L2 learners whose mean accuracy scores for ungrammatical sentences were below chance obtained a mean score of $0.20(\mathrm{SD}=0.24)$ for verbal passives, the same as the whole group of L2 learners. However, their mean for adjectival passives was lower, $0.65(\mathrm{SD}=0.25)$, than the group average $0.80(\mathrm{SD}=0.24)$.

Data from the bilingual language questionnaire showed that the five HL learners whose mean accuracy scores with verbal passives were above 0.75 used Spanish when talking to their parents especially when they were between six and eleven years old, and three of them attended bilingual programs in elementary school. This contrasts with the four HL learners who scored below 0.08 with these clauses, who used English when talking to their parents during this age period and did not attend bilingual programs. These data suggest that early language use and instruction are potentially determining factors in the comprehension of the verbal passive clauses with era.

Learners' mean accuracy scores in the grammaticality of the verbal passive (i.e., $\mathrm{La}$ cena era servida por los meseros. "Dinner was (ser-IMPERFECT) served by the waiters") were not correlated to their mean scores in the comprehension of the verbal passive (i.e., La cena era

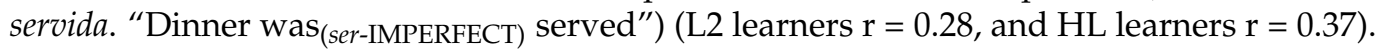




\section{Discussion}

This study investigated comprehension of Spanish adjectival and verbal passives by heritage language learners and second language learners of Spanish. Although both passive clauses are acquired early, by age four, the verbal passive is mastered and developed with literacy at a later age during the school-age period. To contribute to current theoretical debates on the role of linguistic experience associated with age in L2 and bilingual language acquisition, and to contribute to current pedagogical inquiries on how instruction can be beneficial for HL learners, this study investigated whether age of onset of meaningful exposure and type of linguistic experience associated to it affected the acquisition and development of structures of later language development. As a result of their linguistic experience, speakers show their knowledge best in different types of task. For this reason, the present study also investigated whether the modality of the task, aural and written, affected adult L2 learners' and HL learners' comprehension of verbal and adjectival passives. Since a direct result of Spanish instruction is learning the language, we also investigated whether the amount of Spanish instruction affected the comprehension of passives, given that the verbal passive is almost exclusively used in written texts. Related to instruction is the proficiency attained in the HL or L2; hence, we also analyzed whether oral and written proficiency accounted for learners' performance with these passives.

Comprehension of verbal passives with the copula in the imperfect tense (era) as opposed to the comprehension of adjectival passives with the copula in the imperfect tense (estaba) was predicted to be more difficult for both groups of learners. Factors that would make comprehension of verbal passives more difficult were, first, the fact that there is a canonical construction for the verbal passive clause in the past with the copula in the preterite tense (fue) with which learners are more familiar; second, that MRNS use a more frequent passive voice construction, the reflexive passive, also known as morphological passive or se-passive; third, that the verbal passive is not common in oral communication; and, lastly, that the imperfect tense is vulnerable in L2 and HL learners' grammars.

The study included truncated passive clauses with actional verbs and irreversible contexts, such that the theme could not perform the action stated by the verb. Instead, the theme was always the object of, or was in a state resulting from, the action stated by the verb. Both passives were formed with past participles. See examples repeated in (19) and (20) for convenience.

19.

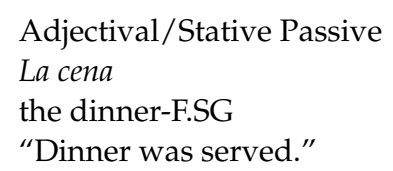

esta-ba serv-ida.

be-estar-IMPERFECT.SG serve-PTCP.F.SG

er-a

be-ser-IMPERFECT.SG serv-ida. serve-PTCP.F.SG

To comprehend adjectival passives with participles, learners had to realize that a description of a state or final result followed the copula estar. To comprehend verbal passives, learners had to know the meaning of the imperfect form era in the verbal passive, which refers to an ongoing or habitual action in the past. Comprehension of these passives required not only knowledge of its syntax but also of the complementary distribution of ser and estar. Acquiring the complementary distribution of the copulas is a hard task for L2 learners and HL learners because they need to acquire not only the irregular inflectional morphology of the copulas but also the contrasts between each copula in syntax, semantics, and pragmatics, which are not present in English. 
As predicted, L2 and HL learners were more accurate with adjectival passives with the copula in the imperfect tense (estaba) than with verbal passives with the copula in the imperfect tense (era). These difficulties in the comprehension of verbal passives show that learners have not acquired the full spectrum of copula uses, confusing era in the verbal passives with estaba in an adjectival passive, which is a simpler construction. It could be argued that the absence of the agent in the verbal passive could have misled learners to interpret them as adjectival passives, but the results of the GJT also showed that learners judged full verbal passives with era (with the agent included in a "by agent" phrase) significantly less acceptable than full verbal passives with the copula in the canonical past tense (fue).

Our results may provide clues for why in previous studies (Valenzuela et al. 2015; Bruhn de Garavito and Valenzuela 2008), L2 and HL learners showed low acceptability ratings for the verbal passive with era. Learners' misinterpretation of this structure may be rooted in a grammar that has yet to incorporate the verbal passive with the copula ser in the imperfect. After completing the tasks, most MRNS said that they preferred to use other passive constructions instead of the verbal passive with the copula in the imperfect. Although native speakers' grammar allows this interpretation, it is not their preferred construction when it comes to use.

Even though passives are acquired early but mastered later in childhood, the age of meaningful exposure to the target language proved to be a robust predictor of successful language acquisition. HL learners were significantly more accurate than L2 learners in the comprehension of adjectival passives and, contrary to our prediction, of verbal passives, too. This means that early exposure to Spanish conferred on HL learners an advantage in the comprehension of complex syntax. It also conferred grammatical knowledge at the interface between morphology, semantics, and syntax, even when this knowledge is consolidated later with literacy. Spanish-speaking children growing up in a Spanishspeaking country acquire verbal passives with non-reversible contexts (like the ones used in this study) by age three, but comprehension of these clauses is unstable at least until ages five to six (Pierce 1992). For most HL learners in the U.S., literacy begins in English at age five. It is remarkable that as adults, after being immersed in an environment in which English is the primary or only language of instruction, they have not lost this knowledge. However, HL learners' accuracy with these clauses was not at ceiling, which indicates that there is individual variability in knowledge of the intricacies of the copulas or of verbal passives. The sources of this variability remain an empirical question.

However, if we take into consideration that of the five HL learners whose mean accuracy scores with verbal passives was closer to $100 \%$, three attended bilingual schools, and all had in common frequent Spanish use (between the ages of six and ten). We can say that early Spanish instruction and opportunities to produce the language at an early age also helps to prevent erosion of the uses of era, and, consequently, the comprehension of verbal passives. This scenario aligns with recent HL studies showing that even if acquired as a minority language, when more input and early education is provided in the $\mathrm{HL}$, the difference between ultimate attainment in monolingual language acquisition and ultimate attainment in bilingual language acquisition is reduced (Montrul 2016; Kupisch and Rothman 2016). In addition, results from these participants show that consistently producing the language (i.e., output) at an early age, which is possible in a bilingual program, could be equally important. Other studies show the importance of output to "add knowledge to their language" ... "Using a language (i.e., output) forces the learner to process the language in a way that only hearing it (i.e., input) does not." (Bohman et al. 2010, 339). Unsworth (2015) and Au et al. (2008) also found that output better predicted children's performance in their HL. Therefore, although early exposure to Spanish helped in the comprehension of passive clauses, those whose HL was reinforced with early HL education and opportunities to produce the language in academic contexts performed more target-like. However, it seems that HL output during an early age helps, too. Thus, 
effects of language output and early instruction in Spanish ought to be investigated in ultimate attainment of the HL especially for complex syntax and semantics.

Confirming results from previous studies, we also found effects of modality in HL learners' comprehension of the passives and in L2 learners' judgment of ungrammatical simple sentences with copulas in the imperfect tense. HL learners were significantly more accurate in the comprehension of passives in the aural modality than in the written modality, and L2 learners were more accurate in judging ungrammatical sentences in the written modality than in the aural modality. We argue that a possible explanation is that L2 learners were simply not familiar with the verbal passives with era, as they were with the copulas in the simple sentences. Results for the learners could mean that when they are under time pressure trying to comprehend structures that are challenging for them, they rely on their more developed skills. Thus, passives were challenging (but overall not completely impossible to understand) for HL learners, and they used their aural skills to serve them in the aural comprehension of these clauses. Similarly, the ungrammatical sentences with copulas in the imperfect were challenging but doable for L2 learners, and their more developed skill helped them in this task. Consistent with typical language acquisition and development in which written language builds on oral language, results for HL learners suggest that previous oral language experience predicts success with structures common in written language. This effect was not seen with L2 learners, because there was no challenge in comprehension of the passives. L2 learners were just not familiar with the differences in copula use between verbal and adjectival passives as they were with copulas in the simple sentences.

Years of Spanish instruction significantly accounted for L2 learners' comprehension of passives, but this variable was not relevant for the HL learners. While these results are consistent with the fact that L2 learners received more education in Spanish than the HL learners, they do not imply that instruction effects can be discarded for HL learners, as discussed above.

A direct and expected consequence of Spanish instruction is reaching higher proficiency in the Spanish language. Thus, effects of instruction and proficiency attained in Spanish in the acquisition and development of passives in the two groups of learners were analyzed. Four proficiency measures were collected, DELE (as the written proficiency measure) and moving average type/token ratio (MATTR), mean length of utterance (MLU), and fluency in words/minute as the oral proficiency measures. Proficiency in DELE and in MLU accounted for HL learners' comprehension of passive clauses. None of the proficiency measures accounted for L2 learners' performance with passives most likely because they have not learned the verbal passive clauses with era yet.

Let us note that HL and L2 learners' mean accuracy scores for DELE and for MLU did not differ significantly. The written proficiency measure tested knowledge of vocabulary, verbal conjugations, prepositions, and adjectives. MLU is the ratio of the number words to the number of utterances, which is used to measure first language development (Bley-Vroman 1990), and in bilingual language acquisition, it is used to measure language dominance (Unsworth et al. 2018). None of these measures accounted for L2 learners' comprehension of passives, but they did account for comprehension by the HL learners. These findings support the explanation that L2 learners do not know the verbal passives with ser in the imperfect tense.

In the case of L2 learners, they interpreted the first noun of verbal passives as the subject and failed to integrate the meaning of the copula ser that would have led them to interpret it correctly as the theme of a verbal passive. The interpretation of verbal passives as adjectival passives does not change even as proficiency increases, which brings about the question of whether this would be the case if the verbal passive with the copula in the imperfect tense was explicitly taught. Indeed, previous studies have shown that some types of instruction facilitate L2 learners' comprehension of passives (Lee 2015). Although the type of teaching practice best suited to teach verbal passives in the imperfect tense is an empirical question, instructional materials used to teach the difference between these two 
passives have to take into consideration factors such as the learners' developmental level and L1 influence. Ser in the verbal passives is the last copular function that L2 learners acquire (Briscoe 1995), and only advanced L2 learners have been shown to discriminate between preterite and imperfect past tenses (Montrul and Slabakova 2003). Another factor to take into account is that English does not have a direct equivalence for the copular contrast ser/estar.

A limitation of our study is that it did not include a measure of working memory in this design, which could have helped in interpreting results for HL learners who were highly accurate with the verbal passives. Replicating this study with illiterate or low literacy monolingual speakers could tell us more about the capacities of oral language development. Despite these caveats, the current study makes a unique contribution to the field, because it provides evidence that in Spanish, age effects can be seen even with structures of later language development. More importantly, this study suggests that early exposure to a language paired with early instruction and opportunities to produce the language reinforce HL knowledge. In addition, by using two modalities to evaluate HL and L2 learners' grammar knowledge and proficiency, this study confirms the need to use two testing modalities in research and classroom settings that align with the learners' strengths to avoid biases that favor only one group of learners to the detriment of the other. Finally, our study points to the need to improve instructional strategies in HL and L2 Spanish instruction of copulas, especially when they occur in infrequent structures where the copula has important communicative value.

Author Contributions: Conceptualization, N.S.W. and S.M.; Formal analysis, N.S.W.; Investigation, N.S.W.; Methodology, N.S.W. and S.M.; Supervision, S.M.; Writing—original draft, N.S.W.; Writingreview \& editing, NSW and S.M. All authors have read and agreed to the published version of the manuscript.

Funding: This research received no external funding.

Institutional Review Board Statement: The study was conducted in accordance with the Declaration of Helsinki, and the protocol was approved by the Office for the Protection of Research Subjects of the Institutional Review Board at the University of Illinois at Urbana-Champaign (IRB Protocol Number 15943).

Informed Consent Statement: All subjects gave their informed consent for inclusion before they participated in the study.

Data Availability Statement: The data presented in this study are available upon request from the corresponding author.

Acknowledgments: This research was partly funded by a UIUC Department of Spanish and Portuguese Summer Research Fellowship. We are thankful to Maria Lux and Maggie Shuo Feng who created and digitally traced drawings, and to Cristina Mostacero Pinilla for her help as an interrater for the oral narratives. We also thank the Second Language Acquisition and Bilingualism (SLAB) Lab at UIUC where most testing took place, and the Illinois Phonetics \& Phonology Lab at UIUC where most of the audio files were graciously recorded by Gerardo Villalobos and Héctor G. Arce. We sincerely thank the anonymous reviewers for their careful reading of our manuscript and helpful comments and suggestions. All errors remain our own.

Conflicts of Interest: The authors declare no conflict of interest. 


\section{Appendix E. Bilingual Language Questionnaire}

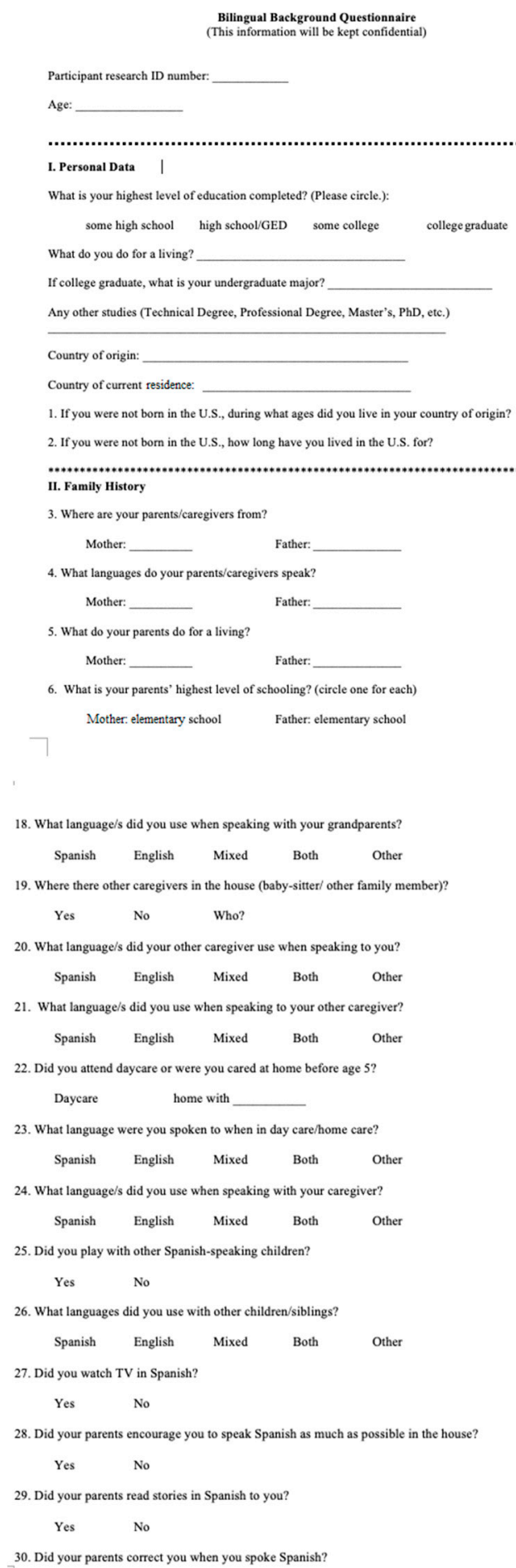


41. Did you attend middle school in the US?

$$
\text { Yes No }
$$

42. Was English the primary language of instruction?

$$
\text { Yes No }
$$

43. Did you have Spanish as a foreign/second language in middle school?

Yes No

44. How many hours a week of Spanish did you have in middle school?

$$
2 \text { hours } 5 \text { hours } 10 \text { hours more than } 10 \text { hours }
$$

45. Did you have Spanish-speaking friends in middle school?

$$
\text { Yes No }
$$

46. What language did you speak with your Spanish-speaking friends in middle school?

$$
\text { Spanish English Both }
$$

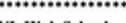

VI. High School

47. How often did you use Spanish between the ages 13-17?

$$
\text { always often seldom never }
$$

48. Who did you speak Spanish with?

$$
\text { mother/father siblings friends others }
$$

49. Did you attend high school in the US?

$$
\text { Yes No }
$$

50. Was English the language of instruction?

$$
\text { Yes No }
$$

51. Did you have Spanish as a foreign/second language in high school?

$$
\text { Yes No }
$$

52. How many hours a week of Spanish did you have in high school?

$$
2 \text { hours } 5 \text { hours } 10 \text { hours more than } 10 \text { hours }
$$

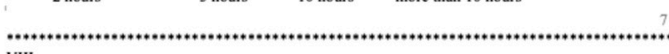

61. Would you like to improve your Spanish language skills?

$$
\text { Yes No Why? }
$$

62. What would you like to improve about your Spanish language ability?

63. How is Spanish important for you?

64. Do you think it is important to maintain and improve Spanish in your life?

65. How do you think you can use more Spanish in your future?

66. What was your undergraduate major?

67. Have you lived in a Spanish speaking country? For how long? 68. Please try to remember and list all the Spanish classes you have taken and indicate on a scale of 1 to 7
how much it helped you in your Spanish language development. A score of 1 means the course did not help you at all, a score of 7 means it helped you greatly

Ex. Spanish writing - 7 -school - this course helped me a lot.

Conversational Spanish - summer camp -4 , I did learn one thing or two, not that much.

Elementary school:

Middle School:

High School:
53. Did you have Spanish-speaking friends in high school?

$$
\text { Yes No }
$$

54. What language did you speak with your Spanish-speaking friends in high school?

$$
\text { Spanish English Mixed Both }
$$

55. Did you travel to a Spanish-speaking countries?

Where When How long How often

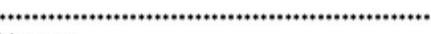

VII. Your linguistic proficiency now

56. Rate your current overall language ability in ENGLISH

1 - understand but cannot speak
2 - understand and can speak with great difficulty $3=$ understand and speak but with some difficulty
$4=$ understand and speak comfortably, with little difficulty $4=$ understand and speak comfortably, with little difficulty
5 - understand and speak fluently like a native speaker

57. Rate your current overall language ability in SPANISH

1 - understand but cannot speak

$2=$ understand and can speak with great difficulty
$3=$ understand and speak but with some difficulty 4 = understand and speak comfortably, with little difficulty 5 - understand and speak fluently like a native speaker

58. On a scale from 1 to 5 , rate your abilities in English and in Spanist

( 1 -poor; $2=$ needs work; 3 -good; 4- very good; $5=$ native speaker command

$\begin{array}{lllll}\text { English } & \text { Reading - } & \text { Speaking-- } & \text { Listening- } & \text { Writing- } \\ \text { Spanish } & \text { Reading- } & \text { Speaking-- } & \text { Listening- } & \text { Writing- }\end{array}$

59. In general, as a young adult, which language do you prefer to use? (circle one)

$$
\begin{array}{lll}
\text { English } & \text { Spanish } & \begin{array}{l}
\text { It depends } \\
\text { on whom I talk to }
\end{array}
\end{array}
$$

60. Do you feel Spanish is your native language or like a second language?

$$
\text { Native language second language }
$$




\section{Appendix F}

GJT sentences

Grammatical sentences had era, shown below.

Ungrammatical sentences had the copula estaba.

1. La cena era servida por los meseros.

Dinner was being served by the waiters.

2. El paciente era medicado por los médicos.

The patient was being medicated by the doctors.

3. La cortina era colgada por la diseñadora.

The curtain was being hung by the designer.

4. El carro era vandalizado por los delincuentes.

The car was being vandalized by the criminals.

5. La ropa era lavada por las mujeres.

The clothes were being washed by the women.

6. La chica era peinada por la estilista.

The young woman was being coiffed by the stylist.

7. El submarino era hundido por los barcos.

The submarine was being sunk by the boats.

8. El platillo era destruido por los aviones.

The saucer was being destroyed by the planes.

9. El coche era abollado por los autobuses.

The car was being dented by the buses.

10. La caja era acomodada por el empleado.

The box was being placed by the employee.

11. La bicicleta era arreglada por el ciclista.

The bicycle was being fixed by the cyclist.

12. La puerta era cerrada por los caballeros.

The door was being closed by the knights.

13. El castillo era construido por los plebeyos.

The castle was being built by the plebeians.

14. El árbol era adornado por los niños.

The tree was being decorated by the children.

15. La manzana era picada por el chef.

The apple was being sliced by the chef.

16. El hombre era maquillado por la chica.

The man was being "made up" by the young woman.

17. El cuchillo era amolado por el hombre.

The knife was being sharpened by the man.

18. La antena era fijada por el marido.

The antenna was being affixed by the husband.

19. El café era colado por el barista.

The coffee was being strained by the barista.

20. La carta era escrita por el chico.

The letter was being written by the young.

21. La solicitud era rellenada por los solicitantes.

The application was being filled out by the applicants.

22. El barro era moldeado por los estudiantes.

The clay was being shaped by the students.

23. La cenicienta era transformada por el hada madrina.

Cinderella was being transformed by the fairy godmother.

24. La computadora era ensamblada por el chico.

The computer was being assembled by the young man. 


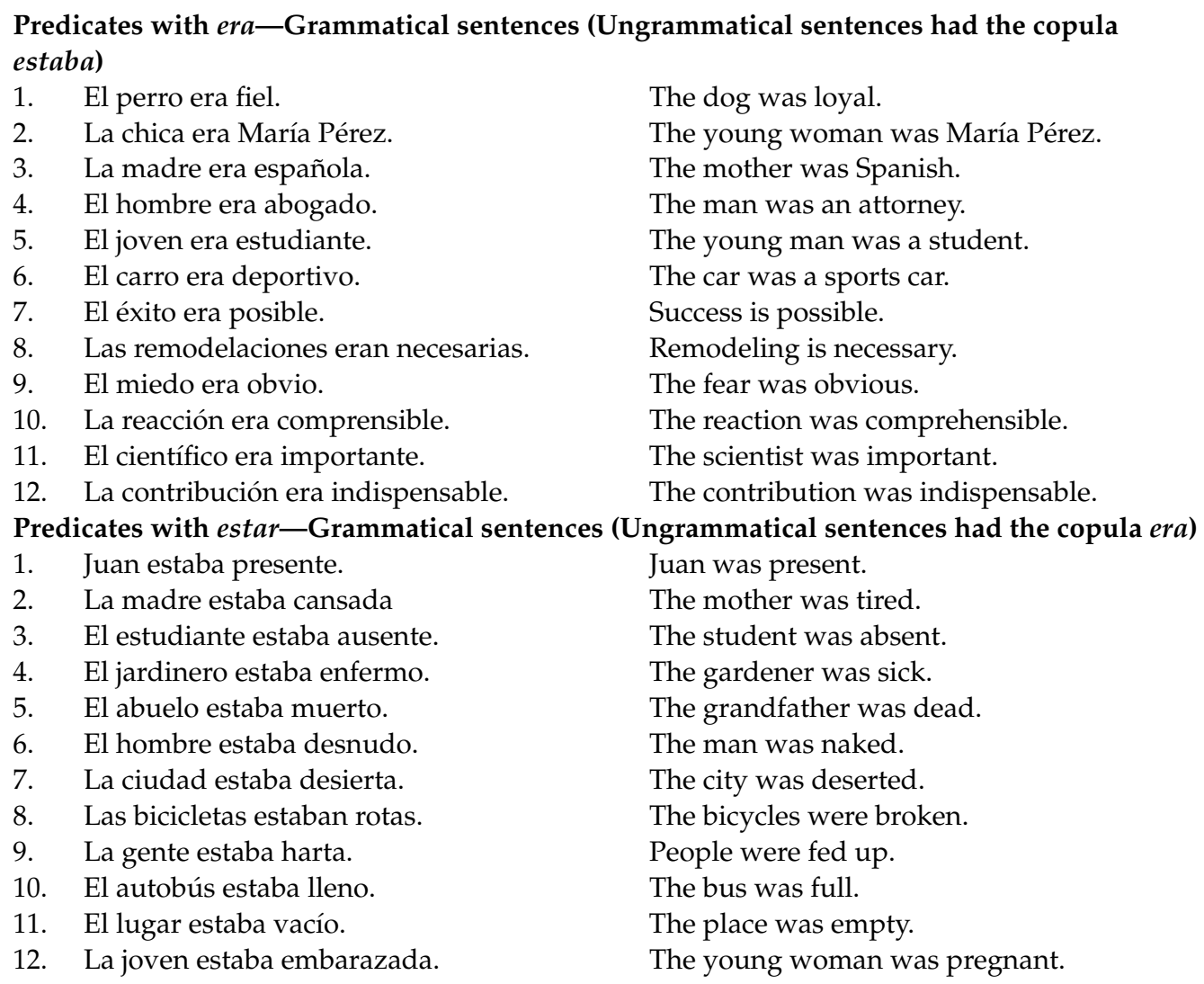

Prepositional phrases with Estar-Grammatical (Ungrammatical sentences had the copula era)

1. El chico estaba en la tienda.

2. El coco estaba en la palma.

3. El gato estaba en el sofá.

4. El perro estaba en el patio.

5. La chica esaba en la tienda.

6. Las chicas estaban en la tienda.

7. Los chicos estaban en la tienda.

8. Los cocos estaban en la palma.

9. Los gatos estaban en el sofá.

10. Los hombres estaban en el trabajo.

11. Los perros estaban en el patio.

12. La mujer estaba en el trabajo.

Prepositional phrases with Ser-Grammatical (Ungrammatical sentences had the copula estaba)

1. La torre era de piedra.

2. La chica era de México.

3. El parapente era de plástico.

4. Los cocos eran de Puerto Rico.

5. Los helicópteros eran del ejército.

6. Las camisas eran de Marta.

7. Las gafas eran de la abuela.

8. Los médicos eran de Costa Rica.

9. Los bates eran del chico.

10. El bate era de madera.

11. La bicicleta era de Ramón.

12. El submarino era de titanio.
The young man was at the store.

The coconut was on the coconut palm.

The cat was on the sofa.

The dog was in the backyard.

The young woman was at the store.

The young women were at the store.

The young men were at the store.

The coconuts were on the coconut palm.

The cats were on the sofa.

The men were at work.

The dogs were in the backyard.

The woman was at work.

The tower was made out of stone.

The young woman was from Mexico.

The paraglider was made out of plastic

The coconuts were from Puerto Rico.

The helicopters were from the military.

The shirts were Maria's.

It was grandmother's sunglasses.

The doctors were from Costa Rica.

It was the young man's bats.

The bat was made out of wood.

The bicycle was Ramón's.

The submarine was made out of titanium. 


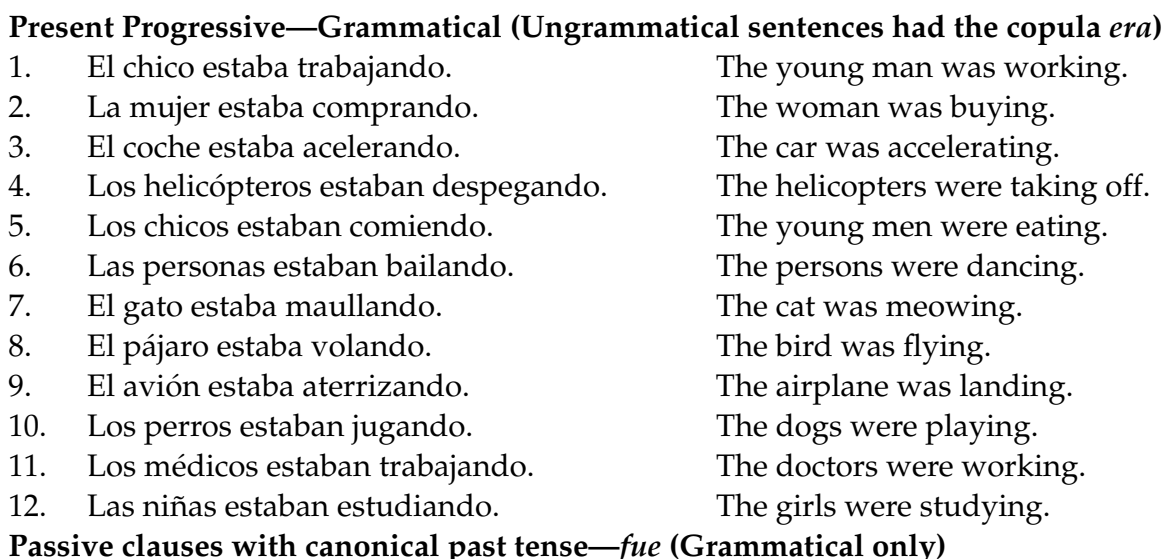

El dragón fue quemado por el volcán.

El platillo fue destruido por los aviones.

El portón fue abollado por los carros.

La paciente fue examinada por el médico.

La mujer fue secuestrada por el criminal.

La niña fue castigada por la mamá.

La motocicleta fue rebasada por los carros.

La camioneta fue remolcada por los carros.

La mujer fue asesinada por el criminal.

El barco fue alumbrado por el faro.

El robot fue destruido por las naves.

El helicóptero fue levantado por las grúas.
The dragon was burned by the volcano. The flying saucer was destroyed by the airplanes.

The gate was dented by the cars.

The patient was examined by the doctor.

The woman was kidnapped by the criminal.

The girl was punished by the mother.

The motorcycle was overtaken by the cars.

The truck was towed by the cars.

The woman was murdered by the criminal.

The boat was illuminated by the lighthouse.

The robot was destroyed by the vessels.

The helicopter was lifted by the cranes.

\section{Appendix G}

Appendix G.1. PMT Sentences-Passive Clauses

1.

2.

3.

4.

5.

6.

7.

8.

9.

10.

11.

12.

13.

14.

15.

16.

17.

18.

19.

20.

21.

22.

23.

24.

25.
La cena era servida.

La cena estaba servida.

El paciente era medicado.

El paciente estaba medicado.

La cortina era colgada.

La cortina estaba colgada.

El carro era vandalizado.

El carro estaba vandalizado.

La ropa era lavada.

La ropa estaba lavada.

La chica era peinada.

La chica estaba peinada.

El submarino era hundido.

El submarino estaba hundido.

El platillo era destruido.

El platillo estaba destruido.

El coche era abollado.

El coche estaba abollado.

La caja era acomodada.

La caja estaba acomodada.

La bicicleta era arreglada.

La bicicleta estaba arreglada.

La puerta era cerrada.

La puerta estaba cerrada.

El castillo era construido.
Dinner was being served.

Dinner was served.

The patient was being medicated.

The patient was medicated.

The curtain was being hung.

The curtain was hung.

The car was being vandalized.

The car was vandalized.

The clothes were being washed.

The clothes were washed.

The woman was being coiffed.

The woman was coiffed.

The submarine was being sunk.

The submarine was sunk.

The flying saucer was being destroyed.

The flying saucer was destroyed.

The car was being dented.

The car was dented.

The box was being placed.

The box was placed.

The bicycle was being fixed.

The bicycle was fixed.

The door was being closed.

The door was closed.

The castle was being built. 
26.

27.

28.

30.

31.

32.

33.

34.

35.

36.

37.

38.

39.

40.

41.

42.

43.

44.

45.

46.

47

48.
El castillo estaba construido.

El árbol era adornado.

El árbol estaba adornado.

La manzana era picada.

La manzana estaba picada.

El hombre era maquillado.

El hombre estaba maquillado.

El cuchillo era amolado.

El cuchillo estaba amolado.

La antena era fijada.

La antena estaba fijada.

El café era colado.

El café estaba colado.

La carta era escrita.

La carta estaba escrita.

La solicitud era rellenada.

La solicitud estaba rellenada.

El barro era moldeado.

El barro estaba moldeado.

La cenicienta era transformada.

La cenicienta estaba transformada.

La computadora era ensamblada.

La computadora estaba ensamblada.
The castle was built.

The tree was being decorated.

The tree was decorated.

The apple was being sliced.

The apple was sliced.

The man was being made up.

The man was wearing makeup.

The knife was being sharpened.

The knife was sharpened.

The antenna was being affixed.

The antenna was affixed.

The coffee was being strained.

The coffee was strained.

The letter was being written.

The letter was written.

The application was being filled out.

The application was filled out.

The clay was being shaped.

The clay was shaped.

Cinderella was being transformed.

Cinderella was transformed.

The computer was being assembled.

The computer was being assembled.

\section{Appendix G.2. PMT Drawings}

Due to copyrights, other drawings are available upon request. Letters " $\mathrm{A}$ " and " $\mathrm{B}$ " in drawings appeared uniformly sized in the E-Prime task. 


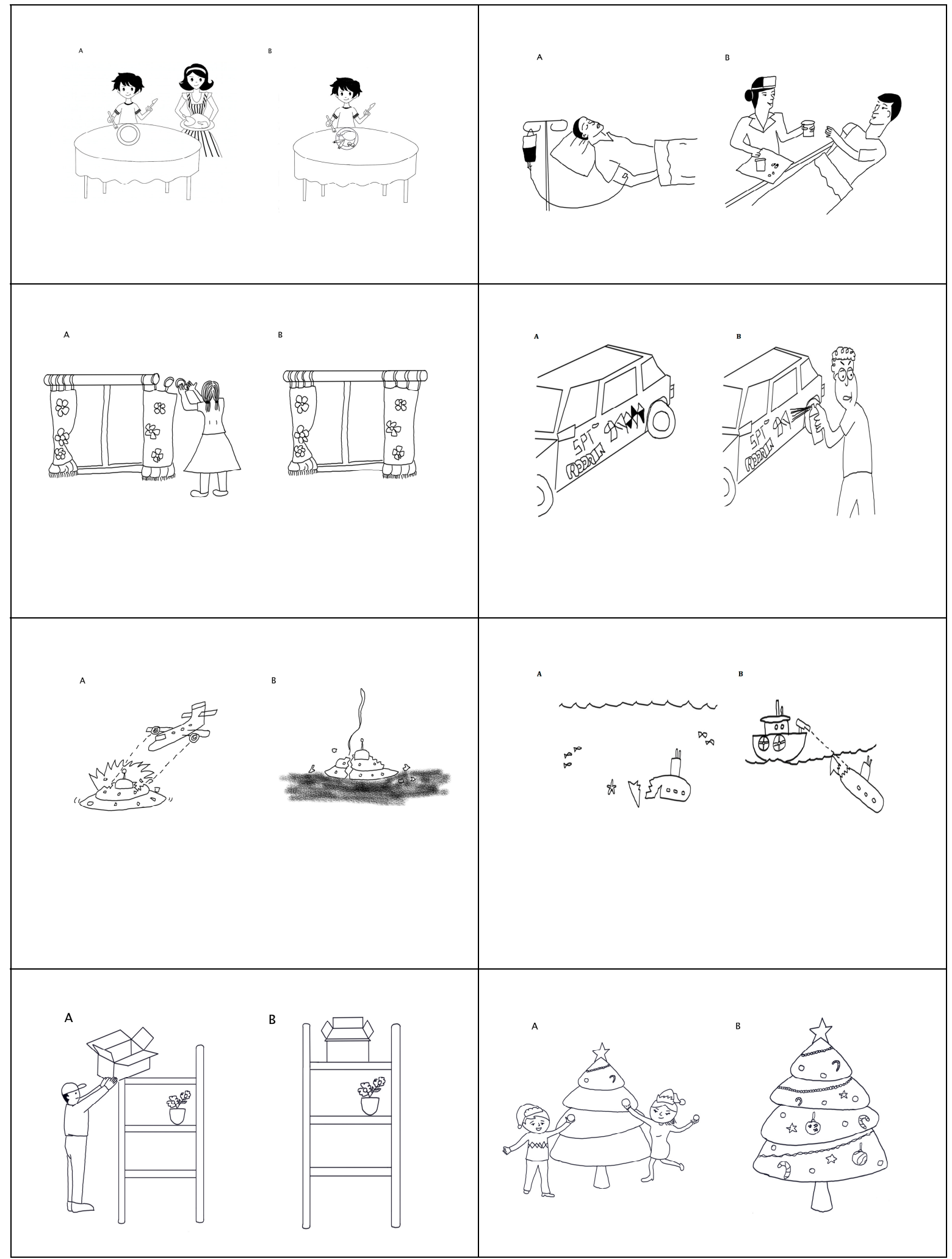

\section{References}

AnalystSoft Inc. 2019. StatPlus:mac. Statistical analysis program for macOS ${ }^{\circledR}$. Version v7. Available online: http:/ www.analystsoft. com/en/ (accessed on 19 December 2020).

Anderson, Raquel T. 1999. Loss of Gender Agreement in L1 Attrition: Preliminary Results. Bilingual Research Journal 23: $389-408$. [CrossRef] 
Archer, María J., Antonio Fábregas, and Rafael Marín. 2019. Main Questions in the Study of Copulas: Categories, Structures, and Operations. In The Grammar of Copulas across Languages. Edited by María J. Arche, Antonio Fábregas and Rafael Marín. Oxford: Oxoford University Press, pp. 1-30.

Armon-Lotem, Sharon, Ewa Haman, Kristine Jensen de López, Magdalena Smoczynska, Kazuko Yatsushiro, Marcin Szczerbinski, Angeliek van Hout, Ineta Dabašinskienè, Anna Gavarró, Erin Hobbs;, and et al. 2016. A Large-Scale Cross-Linguistic Investigation of the Acquisition of Passive. Language Acquisition 23: 27-56. [CrossRef]

$\mathrm{Au}$, Terry Kit Fong, Janet S. Oh, Leah M. Knightly, Sun Ah Jun, and Laura F. Romo. 2008. Salvaging a Childhood Language. Journal of Memory and Language 58: 998-1011. [CrossRef] [PubMed]

Barr, Dale J., Roger Levy, Christoph Scheepers, and Harry J. Tily. 2013. Random Effects Structure for Confirmatory Hypothesis Testing: Keep It Maximal. Journal of Memory and Language 68: 255-78. [CrossRef]

Bates, Douglas, Martin Maechler, Ben Bolker, and Steve Walker. 2015. Fitting Linear Mixed-Effects Models Using Lme4. Journal of Statistical Software 67: 1-48. [CrossRef]

Bayram, Fatih, Tanja Kupisch, Diego Y. Pascual Cabo, and Jason Rothman. 2019. Terminology Matters on Theoretical Grounds Too! Coherent Grammars Cannot Be Incomplete. Studies in Second Language Acquisition 41: 257-64. [CrossRef]

Berman, Ruth, and Dan Slobin, eds. 1994. Relating Events in Narrative: A Crosslinguistic Developmental Study. Hillsdale: Lawrence Erlbaum.

Bley-Vroman, Robert. 1990. What Is the Logical Problem of Foreign Language Learning? Linguistic Analysis 20: 3-49. [CrossRef]

Bohman, Thomas M., Lisa M. Bedore, Elizabeth D. Peña, Anita Mendez-Perez, and Ronald B. Gillam. 2010. What You Hear and What You Say: Language Performance in Spanish-English Bilinguals. International Journal of Bilingual Education and Bilingualism 13: 325-44. [CrossRef]

Borer, Hagit, and Kenneth Wexler. 1987. The Maturation of Syntax. In Parameter-Setting. Studies in Theoretical Psycholinguistics. Edited by Thomas Roeper and Edwin Williams. Dordrecht: Springer, pp. 123-72. [CrossRef]

Borer, Hagit, and Kenneth Wexler. 1992. Bi-Unique Relations and the Maturation of Grammatical Principles. Natural Language and Linguistic Theory 10: 147-189. [CrossRef]

Bowles, Melissa. 2011a. Exploring the Role of Modality: L2-Heritage Learner Interactions in the Spanish Language Classroom. Heritage Language Journal 8: 30-65.

Bowles, Melissa. 2011b. Measuring Implicit and Explicit Knowledge: What Can Heritage Learners Contribute? Studies in Second Language Acquisition 33: 247-71. [CrossRef]

Bowles, Melissa. 2018. Outcomes of Classroom Spanish Heritage Language Instruction. In The Routledge Handbook of Spanish as a Heritage Language. Edited by Kim Potwoski. London and New York: Routledge Taylor \& Francis Group, pp. 331-44. [CrossRef]

Bowles, Melissa, and Silvina Montrul. 2008. The Role of Explicit Instruction in the L2 Acquisition of the A-Personal. In Selected Proceedings of the 10th Hispanic Linguistics Symposium. Edited by Joyce Bruhn de Garavito and Elena Valenzuela. Somerville, MA: Cascadilla Proceedings Project, pp. 25-35.

Briscoe, Gregory Gene. 1995. The Acquisition of Ser and Estar by Non-Native Speakers of Spanish. Ph.D. dissertation, University of Pennsylvania, Philadelphia, PA, USA. Available online: https://repository.upenn.edu/dissertations / AAI9532145 (accessed on 1 June 2019).

Brown, Esther, and Mayra Cortés-Torres. 2012. Syntactic and Pragmatic Usage of the [Estar + Adjective] Construction in Puerto Rican Spanish: Está Brutal. In Selected Proceedings of the 14th Hispanic Linguistics Symposium. Edited by Kimberly L. Geeslin and Manuel Díaz-Campos. Somerville: Cascadilla Proceedings Project, pp. 61-74. ISBN 978-1-57473-450-8.

Bruhn de Garavito, Joyce, and Elena Valenzuela. 2006. The Status of Ser and Estar in Late and Early Bilingual L2 Spanish. In Selected Proceedings of the 7th Conference on the Acquisition of Spanish and Portuguese as First and Second Languages. Cascadilla Proceedings Project. Edited by Carol A. Klee and Timothy L. Face. Cambridge: Cambridge University Press, pp. 100-109.

Bruhn de Garavito, Joyce, and Elena Valenzuela. 2008. Eventive and Stative Passives in Spanish L2 Acquisition: A Matter of Aspect. Bilingualism 11: 323-336. [CrossRef]

Bylund, Emanuel. 2009. Maturational Constraints and First Language Attrition. Language Learning 59: 687-715. [CrossRef]

Camacho, José. 2012. Ser and Estar: The Individual/Stage-Level Distinction and Aspectual Predication. In The Handbook of Hispanic Linguistics, 1st ed. Edited by José Ignacio Hualde, Antxon Olarrea and Erin O’Rourke. Hoboken: Blackwell Publishing Ltd., pp. 453-75.

Carreira, Maria, and Olga Kagan. 2011. The Results of the National Heritage Language Survey: Implications for Teaching, Curriculum Design, and Professional Development. Foreign Language Annals 44: 40-64. [CrossRef]

Comajoan Colomé, Llorenç. 2014. Tense and Aspect in Second Language Spanish. In The Handbook of Spanish Second Language Acquisition. Edited by Kimberly L. Geeslin. Hoboken: John Wiley \& Sons, Inc., pp. 235-52.

Crain, Stephen, Rosalind Thornton, and Keiko Murasugi. 2009. Capturing the Evasive Passive. Language Acquisition 16: 123-33. [CrossRef]

Crawford, Jean Lenore. 2012. Developmental Perspectives on the Acquisition of the Passive. Ph.D. dissertation, University of Connecticut at Storrs, Storrs, CT, USA.

DeKeyser, Robert. 2017. Knowledge and Skill in ISLA. In The Routledge Handbook of Instructed Second Language Acquisition. Edited by Shawn Loewen and Masatoshi Sato. New York: Routledge Taylor and Francis Group, pp. 15-32. 
Domínguez, Laura, Glyn Hicks, and Roumyana Slabakova. 2019a. Terminology Chocie in Generative Acquisition Research the Case of 'Incomplete Acquisition' in Heritage Language Grammars. Studies in Second Language Acquisition 41: 241-55. [CrossRef]

Domínguez, Laura, Glyn Hicks, and Roumyana Slabakova. 2019b. Choice of Words Matters, but so Does Scientific Accuracy: Reply to Peer Commentaries. Studies in Second Language Acquisition 41: 283-86. [CrossRef]

Ellis, Rod. 2005. Measuring Implicit and Explicit Knowledge of a Second Language: A Psychometric Study. Studies in Second Language Acquisition 27: 141-72. [CrossRef]

Ellis, Nick C. 2008. Implicit and Explicit Knowledge of Language. In Encyclopedia of Language and Education, 2nd ed. Edited by Nancy H. Hornberger and Jasone Cenoz. Boston: Springer, vol. 6, pp. 119-31.

Ellis, Rod. 2008. The Study of Second Language Acquisition, 2nd ed. Oxford: Oxford University Press.

Ellis, Rod. 2009. Measuring Implicit and Explicit Knowledge of a Second Language. In Implicit and Explicit Knowledge in Second Language Learning, Testing and Teaching. Edited by Rod Ellis, Shawn Loewen, Catherine Elder, Hayo Reinders, Rosemary Erlam and Jenefer Philp. New York and Bristol: Multilingual Matters, pp. 31-64.

Foote, Rebecca. 2011. Integrated Knowledge of Agreement in Early and Late English-Spanish Bilinguals. Applied Psycholinguistics 32: 187-220. [CrossRef]

Fox, Danny, and Yosef Grodzinsky. 1998. Children's Passive: A View from the by-Phrase. Linguistic Inquiry 29: 311-32. [CrossRef]

García-Pardo, Alfredo. 2017. Aspect and Argument Structure in Adjectival Passives. Borealis: An International Journal of Hispanic Linguistics 6: 21-52. [CrossRef]

Geeslin, Kimberly L. 2003. A Comparison of Copula Choice: Native Spanish Speakers and Advance Learners. Language Learning 53: 703-64. [CrossRef]

Geeslin, Kimberly L. 2013. The Acquisition of the Copula Contrast in Second Language Spanish. In The Handbook of Spanish Second Language Acquisition. Edited by Kimberly Geeslin. Hoboken: Wiley Blackwell, pp. 219-34. [CrossRef]

Geeslin, Kimberly L., and Pedro Guijarro-Fuentes. 2006. Second Language Acquisition of Variable Structures in Spanish by Portuguese Speakers. Language Learning 56: 53-107. [CrossRef]

Gehrke, Berit, and Cristina Marco. 2014. Different By-Phrases with Adjectival and Verbal Passives: Evidence from Spanish Corpus Data. Lingua 149: 188-214. [CrossRef]

Green, John N. 1975. On the Frequency of Passive Constructions in Modern Spanish. Bulletin of Hispanic Studies 52: $345-62$.

Grimshaw, Jane B. 1990. Argument Structure. Linguistic Inquiry Monographs; 18. Cambridge: MIT Press.

Grodzinsky, Yosef. 2000. The Neurology of Syntax: Language Use without Broca's Area. Behavioral and Brain Sciences $23:$ 1-71. [CrossRef]

Huang, Yi Ting, Xiaobei Zheng, Xiangzhi Meng, and Jesse Snedeker. 2013. Children's Assignment of Grammatical Roles in the Online Processing of Mandarin Passive Sentences. Journal of Memory and Language 69: 589-606. [CrossRef]

Jegerski, Jill. 2012. The Processing of Subject Object Ambiguities in Native and Near-Native Mexican Spanish. Bilingualism 15: 721-35. [CrossRef]

Jisa, Harriet, Judy S Reilly, Ludo Verhoeven, Elisheva Baruch, and Elisa Rosado. 2002. Passive Voice Constructions in Written Texts: A Cross-Linguistic Developmental Study. Written Language \& Literacy 5: 163-81. [CrossRef]

Krasinski, Emily. 2005. Acquisition of Ser and Estar in a Bilingual Child. In Contactos y Contextos Lingüísticos el Español en los Estados Unidos y en Contacto con Otras Lenguas. Edited by Luis A. Ortiz-López and Manel Lacorte. Madrid: Lingüística Iberoamericana, pp. 217-26.

Kupisch, Tanja, and Jason Rothman. 2016. Interfaces with Syntax in Language Acquisition. Manual of Grammatical Interfaces in Romance, 1-39. [CrossRef]

Lee, James F. 2015. Processing Instruction on the Spanish Passive with Transfer-of-Training Effects to Anaphoric and Cataphoric Reference Contexts. IRAL-International Review of Applied Linguistics in Language Teaching 53: 203-23. [CrossRef]

Lema, José. 1992. Distinguishing Copular and Aspectual Auxiliaries: Spanish 'ser'and 'estar'. In Contemporary Research in Romance Linguistics. Edited by Jon Amastae, Grant Goodall, Mario Montalbetti and Marianne Phinney. Amsterdam: John Benjamins Publishing Company, pp. 257-74.

Lichtman, Karen. 2013. Developmental Comparisons of Implicit and Explicit Language Learning. Language Acquisition 20: 93-108. [CrossRef]

Loewen, Shawn. 2014. Introduction to Instructed Second Language Acquisition. New York: Routledge Taylor and Francis Group.

Loewen, Shawn, and Masatoshi Sato. 2017. Instructed Second Language Acquisition (ISLA) An Overview. In The Routledge Handbook of Instructed Second Language Acquisition, 1st ed. Edited by Shawn Loewen and Masatoshi Sato. New York and London: Routledge Taylor and Francis Group, pp. 1-12.

Mayberry, Rachel I., and Robert Kluender. 2018. Rethinking the Critical Period for Language: New Insights into an Old Question from American Sign Language. Bilingualism 21: 886-905. [CrossRef] [PubMed]

Merino, Barbara J. 1983. Language Loss in Bilingual Chicano Children. Journal of Applied Developmental Psychology 4: 277-94. [CrossRef]

Miller, Jon, and Aquiles Iglesias. 2016. Systematic Analysis of Language Transcripts (SALT). Students Version 16 [Computer Software]. Madison, WI: SALT Software, LLC.

Montrul, Silvina. 2005. Second Language Acquisition and First Language Loss in Adult Early Bilinguals: Exploring Some Differences and Similarities. Second Language Research 21: 199-249. [CrossRef] 
Montrul, Silvina. 2008a. Form-Meaning Mappings in the Aspectual Domain: What about the L1? A Response to Bruhn de Garavito and Valenzuela. Bilingualism: Language and Cognition 11: 337-39. [CrossRef]

Montrul, Silvina. 2008b. Incomplete Acquisition in Bilingualism: Re-Examining the Age Factor. Philadelphia: John Benjamins Publishing Company.

Montrul, Silvina. 2010. How Similar Are L2 Learners and Heritage Speakers? Spanish Clitics and Word Order. Applied Psycholinguistics 31: 167-207. [CrossRef]

Montrul, Silvina. 2011. Morphological Errors in Spanish Second Language Learners and Heritage Speakers. Studies in Second Language Acquisition 33: 163-92. [CrossRef]

Montrul, Silvina. 2016. The Acquisition of Heritage Languages. Cambridge: Cambridge University Press.

Montrul, Silvina, and Melissa Bowles. 2010. Is Grammar Instruction Beneficial for Heritage Language Learners? Dative Case Marking in Spanish. Heritage Language Journal 7: 47-73. [CrossRef]

Montrul, Silvina, Justin Davidson, Israel de La Fuente, and Rebecca Foote. 2014. Early Language Experience Facilitates the Processing of Gender Agreement in Spanish Heritage Speakers. Bilingualism 17: 118-38. [CrossRef]

Montrul, Silvina, Rebecca Foote, and Silvia Perpiñán. 2008a. Gender Agreement in Adult Second Language Learners and Spanish Heritage Speakers: The Effects of Age and Context of Acquisition. Language Learning 58: 503-53. [CrossRef]

Montrul, Silvina, Rebecca Foote, and Silvia Perpiñán. 2008b. Knowledge of Wh-Movement in Spanish L2 Learners and Heritage Speakers. In Selected Proceedings of the 10th Hispanic Linguistics Symposium. Edited by Joyce Bruhn de Garavito and Elena Valenzuela Somerville, MA: Cascadilla Proceedings Project, Available online: http:/ /www.lingref.com/cpp/hls/10/paper1788.pdf (accessed on 19 December 2020).

Montrul, Silvina, Israel de la Fuente, Justin Davidson, and Rebecca Foote. 2013. The Role of Experience in the Acquisition and Production of Diminutives and Gender in Spanish: Evidence from L2 Learners and Heritage Speakers. Second Language Research 29: 87-118. [CrossRef]

Montrul, Silvina, and Silvia Perpiñán. 2011. Assessing Differences and Similarities between Instructed Heritage Language Learners and L2 Learners in Their Knowledge of Spanish Tense-Aspect and Mood (TAM) Morphology. Heritage Language Journal 8: 90-132.

Montrul, Silvina, and Carmen Silva-Corvalán. 2019. The Social Context Contributes to the Incomplete Acquisition of Aspects of Heritage Languages. Studies in Second Language Acquisition 41: 269-73. [CrossRef]

Montrul, Silvina, and Roumyana Slabakova. 2003. Competence Similarities between Native and Near-Native Speakers an Investigation of The Preterite-Imperfect Contrast in Spanish. Studies in Second Language Acquisition 25: 351-98. [CrossRef]

O'Grady, William. 1997. Syntactic Development. Chicago: The University of Chicago Press.

O'Grady, William, On-Soon Lee, and Jin-Hwa Lee. 2011. Practical and Theoretical Issues in the Study of Heritage Language Acquisition. Heritage Language Journal 8: 315-32.

Pierce, Amy E. 1992. The Acquisition of Passives in Spanish and the Question of A-Chain Maturation. Language Acquisition 2: 55-81. [CrossRef]

Pinker, Steven, David S Lebeaux, and Loren Ann Frost. 1987. Productivity and Constraints in the Acquisition of the Passive. Cognition 26: 195-267. [CrossRef]

Pires, Acrisio, and Jason Rothman. 2009a. Acquisition of Brazilian Portuguese in Late Childhood: Implications for Syntactic Theory and Language Change. In Minimalist Inquiries into Child and Adult Language Acquisition: Case Studies across Portuguese. Edited by Acrisio Pires and Jason Rothman. Berlin: Mouton de Gruyter, pp. 129-54. [CrossRef]

Pires, Acrisio, and Jason Rothman. 2009b. Disentangling Sources of Incomplete Acquisition: An Explanation for Competence Divergence across Heritage Grammars. International Journal of Bilingualism 13: 211-38. [CrossRef]

Polinsky, Maria. 2016. Looking Ahead. In Advances in Spanish as a Heritage Language, 1st ed. Edited by Diego Pascual y Cabo. Amsterdam and Philadelphia: John Benjamins Publishing Company, pp. 325-45. [CrossRef]

Potowski, Kim, Jill Jegerski, and Kara Morgan-Short. 2009. The Effects of Instruction on Language Development. Language Learning 59: 537-79. [CrossRef]

Quesada, J. Diego. 1997. Obituary: Adios to Passive in Spanish. La Linguistique 33: 41-62. Available online: https:/ /www.jstor.org/ stable/30249112 (accessed on 9 November 2020).

R-Core-Team. 2019. A Language and Environment for Statistical Computing. Vienna: R Foundation for Statistical Computing.

Rebuschat, Patrick. 2013. Measuring Implicit and Explicit Knowledge in Second Language Research. Language Learning 63: 595-626. [CrossRef]

Schmitt, Cristina, and Karen Miller. 2007. Making Discourse-Dependent Decisions: The Case Ofthe Copulas Ser and Estar in Spanish. Lingua 117: 1907-29. [CrossRef]

Silva-Corvalán, Carmen. 1986. Bilingualism and Language Change: The Extension of Estar in Los Angeles Spanish. Language 62: 587-608. Available online: https:/ / www.jstor.org/stable/415479 (accessed on 9 November 2020).

Silva-Corvalán, Carmen. 1991. Spanish Language Attrition in a Contact Situation with English. In First Language Attrition, 1st ed. Edited by Herbet W. Seliger and Robert M. Vago. Cambridge: Cambridge University Press, pp. 151-71.

Silva-Corvalán, Carmen. 1994. Language Contact and Change: Spanish in Los Angeles. Oxford: Clarendon Press.

Silva-Corvalán, Carmen. 2003. Linguistic Consequences of Reduced Input in Bilingual First Language Acquisition. In Linguistic Theory and Language Development in Hispanic Languages. Edited by Silvina Montrul and Francisco Ordóñez. Sommerville, MA: Cascadilla Press, pp. 375-397. 
Silva-Corvalán, Carmen. 2014. Bilingual Language Acquisition Spanish and English in the First Six Years. Cambridge: Cambridge University Press.

Silva-Corvalán, Carmen, and Simona Montanari. 2008. The Acquisition of Ser, Estar (and Be) by a Spanish-English Bilingual Child: The Early Stages. Bilingualism 11: 341-60. [CrossRef]

Sudhalter, Vicki, and Martin D. S. Braine. 1985. How Does Comprehension of Passives Develop? A Comparison of Actional and Experiential Verbs. Journal of Child Language 12: 455-70. [CrossRef]

Takagaki, Toshihiro. 2005. On the Productivity of the Spanish Passive Constructions. In Corpus-Based Approaches to Sentence Structures. Edited by Toshihiro Takagaki, Susumu Zaima, Yoichiro Tsuruga, Francisco Moreno Fernández and Yuji Kawaguchi. Amsterdam and Philadelphia: John Benjamins Publishing Company, vol. 2, pp. 289-309. [CrossRef]

Tolchinsky, Liliana, and Elisa Rosado. 2005. The Effect of Literacy, Text Type, and Modality on the Use of Grammatical Means for Agency Alternation in Spanish. Journal of Pragmatics 37: 209-37. [CrossRef]

Torres, Julio. 2018. The Effects of Task Complexity on Heritage and L2 Spanish Development. Canadian Modern Language Review 74: 128-52. [CrossRef]

Ud Deen, Kamil. 2011. The Acquisition of the Passive. In Handbook of Generative Approaches to Language Acquisition. Edited by Tom Roeper and Jill de Villiers. Dordrecht: Springer, vol. 41, pp. 155-87. [CrossRef]

Unsworth, Sharon. 2015. Amount of Exposure as a Proxy for Dominance in Bilingual Language Acquisition. In Language Dominance in Bilinguals: Issues of Measurement and Operationalization. Edited by Carmen Silva-Corvalán and J. Treffers-Daller. Cambridge: Cambridge University Press, pp. 156-73. [CrossRef]

Unsworth, Sharon, Vicky Chondrogianni, and Barbora Skarabela. 2018. Experiential Measures Can Be Used as a Proxy for Language Dominance in Bilingual Language Acquisition Research. Frontiers in Psychology. [CrossRef]

Valenzuela, Elena, Michael Iverson, Jason Rothman, Kristina Borg, Diego Pascual y Cabo, and Manuela Pinto. 2015. Eventive and Stative Passives and Copula Selection in Canadian and American Heritage Speaker Spanish. In New Perspectives on the Study of 'Ser' and 'Estar'. Issues in Hispanic and Lusophone Linguistics. Edited by Isabel Pérez-Jiménez, Manuel Leonetti and Silvia Gumiel-Molina. Amsterdam: John Benjamins, vol. 5, pp. 267-92. [CrossRef]

VanPatten, Bill. 1987. Classroom Learners' Acquisition of Ser and Estar: Accounting for Developmental Patterns. In Foreign Language Learning: A Research Perspective. Edited by Bill VanPatten, Trisha R. Dvorak and James F. Lee. New York and Washington, DC: Newbury House Publishers, pp. 61-75.

Varela, Soledad. 1992. Verbal and Adjectival Participles in Spanish. In Theoretical Analyses in Romance Linguistics. Edited by Christiane Laeufer and Terrell A. Morgan. Amsterdam and Philadelphia: John Benjamins Publishing Company, pp. 219-34.

Vasilyeva, Marina, Heidi Waterfall, Perala B. Gámez, Ligia E. Gómez, Edmond Bowers, and Priya Shimpi. 2010. Cross-Linguistic Syntactic Priming in Bilingual Children. Journal of Child Language 37: 1047-64. [CrossRef]

Wasow, Thomas. 1977. Transformations and the Lexicon. In Formal Syntax. Edited by Peter W. Culicover, Thomas Wasow and Adrian Akmajian. New York: Academic Press, pp. 327-60. 